\title{
Past, present, and future of sustainable finance: insights from big data analytics through machine learning of scholarly research
}

\author{
Satish Kumar',2 - Dipasha Sharma ${ }^{3}$ Sandeep Rao ${ }^{4}$. Weng Marc Lim²,5 . \\ Sachin Kumar Mangla ${ }^{6}$ iD
}

Accepted: 4 November 2021

(c) The Author(s), under exclusive licence to Springer Science+Business Media, LLC, part of Springer Nature 2021

\begin{abstract}
Sustainable finance is a rich field of research. Yet, existing reviews remain limited due to the piecemeal insights offered through a sub-set rather than the entire corpus of sustainable finance. To address this gap, this study aims to conduct a large-scale review that would provide a state-of-the-art overview of the performance and intellectual structure of sustainable finance. To do so, this study engages in a review of sustainable finance research using big data analytics through machine learning of scholarly research. In doing so, this study unpacks the most influential articles and top contributing journals, authors, institutions, and countries, as well as the methodological choices and research contexts for sustainable finance research. In addition, this study reveals insights into seven major themes of sustainable finance research, namely socially responsible investing, climate financing, green financing, impact investing, carbon financing, energy financing, and governance of sustainable financing and investing. To drive the field forward, this study proposes several suggestions for future sustainable finance research, which include developing and diffusing innovative sustainable financing instruments, magnifying and managing the profitability and returns of sustainable financing, making sustainable finance more sustainable, devising and unifying policies and frameworks for sustainable finance, tackling greenwashing of corporate sustainability reporting in sustainable finance, shining behavioral finance on sustainable finance, and leveraging the power of new-age technologies such as artificial intelligence, blockchain, internet of things, and machine learning for sustainable finance.
\end{abstract}

Keywords Sustainable finance $\cdot$ Sustainable development goals $\cdot$ Socially responsible investing · Climate financing · Green financing · Impact investing · Carbon financing • Energy financing $\cdot$ Governance $\cdot$ Big data analytics $\cdot$ Machine learning $\cdot$ Bibliometric analysis $\cdot$ Systematic literature review

Sachin Kumar Mangla

smangla@jgu.edu.in; sachin.kumar@plymouth.ac.uk; sachinmangl@gmail.com

Extended author information available on the last page of the article 


\section{Introduction}

As a universal call to action to end poverty, protect the planet, and improve the lives and prospects of everyone around the world, the 17 Sustainable Development Goals (SDGs) are a part of the 2030 Agenda for Sustainable Development that have been adopted by all United Nations Member States in 2015 and expected to be achieved by 2030 (United Nations, 2020). The United Nations estimates an investment in the range of $\$ 5$ trillion to $\$ 7$ trillion to achieve the SDGs (Craig, 2021). With the unprecedent outbreak of a global pandemic in 2020, the United Nations Development Programme (UNDP) launched the SDG Finance Taxonomy to provide a roadmap for manage the financing and transaction costs of projects that are aligned to the SDGs (Wang et al., 2020). The taxonomy also calls for private capital, finance instruments, and support from financial institutions to contribute toward achieving the SDGs. SDG 17, which is about partnership for goals, is earmarked as a lynchpin for meeting the finance needs required for activities dedicated to achieving the SDGs (MacDonald et al., 2019; Rizzello \& Kabli, 2020).

Sustainable finance has emerged as an important concept at the intersection of finance and the SDGs. More than $\$ 400$ billion of new funds have been raised on capital markets in 2020 , which includes $\$ 357.5$ billion from sustainability bonds and $\$ 76.5$ billion from green bonds (Refinitiv, 2020; United Nations, 2020). The definition of sustainable finance, however, is very broad, encompassing myriad dimensions of sustainable ways to attain finance and investment goals. The European Commission (2021) defines sustainable finance as an evolving process of considering environmental, social, and governance (ESG) factors in financial and investment decisions. However, this definition, which is limited to ESG factors, is very narrow. This calls for a broader and more encompassing definition that speaks to sustainability at large. In this regard, we propose that sustainable finance should encompass all activities and factors that would make finance sustainable and contribute to sustainability, a definition that we opine complements the myriad goals by different stakeholders, such as the European Commission's ESG and the United Nations' SDGs. Indeed, the attainment of sustainable policy objectives across numerous jurisdictions can be achieved through various ways such as climate finance, carbon and ESG disclosure, green bonds, and socially responsible investment (Alsaifi et al., 2020; Barua \& Chiesa, 2019; Lokuwaduge \& Heenetigala, 2017; Migliorelli, 2021; OECD, 2020; Widyawati, 2020), all of which can be covered under our umbrella definition of sustainable finance.

Considering the broad nature of sustainable finance and its importance for achieving the sustainability agenda, many studies have been undertaken to enhance the understanding and practice of sustainable finance. The recent review of sustainable finance by Cunha et al. (2021) exemplifies this observation, as the authors found that the extant literature on sustainable finance to be "excessively fragmented", which makes it difficult to "identify what constitutes the field and what differentiates it from traditional finance". However, their review, which shed light on the critical features of sustainable finance, the global initiatives for the promotion of sustainable finance, and the strategies and outcomes of the main players in sustainable finance, considered 166 articles only, though the field is in fact very much larger, as we demonstrate through the present review consisting of 936 articles. Noteworthily, no review, to date, has attempted to analyze the burgeoning field of sustainable finance without making excessive concessions, wherein overly stringent criteria are imposed to trim the corpus for review to a manageable size for review, as witness in the review by Cunha et al. (2021).

In this study, we aim to provide a state-of-the-art overview of sustainable finance research, taking into account all aspects and related articles in the field. That is to say, this study covers 
the entire spectrum of sustainable finance, and thus, it is not limited to any single aspect of the concept, as in the case of past reviews such as climate finance (Giglio et al., 2020) and green finance (Malhotra \& Thakur, 2020). Moreover, this study uses an objective and a powerful review method, namely bibliometric analysis, which is highly suitable for reviewing fields with a large corpus of articles using quantitative techniques (Donthu et al., 2021a; Pattnaik et al., 2020; Paul et al., 2021). Specifically, bibliometric analysis exemplifies the use of big data analytics through machine learning of scholarly research in two major ways, namely

(1) the search for big data (bibliometrics) is carried out on an artificial intelligence-powered scientific database (Scopus), wherein the scientific database uses specified keywords for supervised machine learning, as a subset of artificial intelligence, to extract large amounts of bibliometric data relating to articles relevant to sustainable finance, and

(2) the analysis of big data (bibliometrics), which is multi-faceted (e.g., journal, author, institution, country, keywords), multi-formatted (e.g., numbers, words), and large-scaled (e.g., thousands of data points across the multiple facets of 936 articles), is powered by unsupervised machine learning, as another subset of artificial intelligence, to discover latent relationships (e.g., interrelated keywords) and the equivalent clusters of latent relationships (e.g., major themes).

In this regard, this study significantly extends Cunha et al.'s (2021) review on sustainable finance to uncover the insights that they were not able to provide due to the inherent limitation of their manual and qualitative review of only a small corpus of the literature. Specifically, this study sheds light on the performance analysis and science mapping of the entire corpus of sustainable finance research using a bibliometric analysis, wherein the former unpacks the publication trend, the top articles and contributing journals, authors, institutions, and countries, and the methodological choices and research contexts, whereas the latter reveals the major themes and topics underpinning the intellectual structure of the field. In doing so, this study will contribute enriching insights that answer six research questions (RQs) that are typically reveal through bibliometric reviews (Donthu et al., 2021b, 2021c; Kumar et al., 2021a, 2021b, 2021c; Rao et al., 2021), and thus, provide a more accurate representation of the state of sustainable finance research as a whole as opposed to the piecemeal representation that emerges from a sample of the field, as in the case of Cunha et al. (2021):

RQ1. What is the publication trend for sustainable finance research?

RQ2. Which are the most influential articles and top contributing journals for sustainable finance research?

RQ3. Which are the top contributing authors, institutions, and countries for sustainable finance research?

RQ4. What methodological choices and research contexts exist for sustainable finance research?

RQ5. What are the major themes and topics for sustainable finance research?

RQ6. What are the future research directions for sustainable finance research?

The insights from this review can be used in several useful ways. First, both new and seasoned researchers in sustainable finance can gain an overview and up-to-date understanding of its publication trend to gauge its interest in the scientific community over time (RQ1). Second, prospective authors can identify key literature (articles, journals) (RQ2), potential collaborators (authors, institutions, countries) (RQ3), as well as methodologies and contexts (RQ4) for sustainable finance research through this review. The same applies for policy makers and industry practitioners who wish to identify experts for consultancy, key literature to inform decisions, as well as methodological and contextual guides for applied research. Third, 
prospective authors can use the major themes and topics revealed through this review as a means to differentiate and position their contributions or novelty against existing streams of sustainable finance research (RQ5). Fourth and finally, prospective authors can gain inspiration from the curation of research directions herein to embark on new and potentially fruitful sustainable finance research (RQ6). These directions can also serve as a teaser into new knowledge that policy makers and industry practitioners can expect to see from the literature in the near future. These contributions, which are typically expected of well-done reviews, are in line with the authoritative guidelines for literature reviews of the field (e.g., Donthu et al., 2021a) and Paul et al., 2021).

The rest of this paper is organized as follows. The paper begins with an overview of sustainable finance. Next, the paper discloses the methodology and reports the findings of the review. Finally, the paper concludes with a future research agenda and a series of research questions for each major theme that can be used as a guide by prospective researchers to advance and fertilize the field of sustainable finance.

\section{Sustainable finance}

The literature on sustainable finance can be traced back to Ferris and Rykaczewski (1986), who addressed the concerns and benefits of social investing in portfolio management. Following this seminal article, the next decade of research (1986-1995) expanded the literature on the key success factors of socially responsible investing (Camey, 1994; Diltz, 1995). New research in the subsequent decade (1996-2005) extended understanding on socially responsible investing in terms of its performance against conventional funds (Guerard \& John, 1997; Hutton et al., 1998; Statman, 2000) and the need to expand its scope to account for ethics (Wilson, 1997) and the environment (Heinkel et al., 2001) such as climate change and renewable energy (Van Der Laan \& Lansbury, 2004). The later decade (2006-2015) sees the introduction and boom of new research such as carbon finance (Aglietta et al., 2015; Bredin et al., 2014; Purdon, 2015; Yenneti \& Gamaralalage, 2012; Yeoh, 2008), climate finance (Brunner \& Enting, 2014; Hogarth, 2012; Jakob et al., 2015; Vanderheiden, 2015), conscious capitalism (Sisodia, 2009, 2013; Wang, 2013a, 2013b), ESG-CSR and firm performance integration (Dorfleitner et al., 2015; Eccles \& Viviers, 2011; Friede et al., 2015; Halbritter \& Dorfleitner, 2015; Himick, 2011; Nielsen \& Noergaard, 2011), and ethical investing (Bauer et al., 2007; Belghitar et al., 2014; Chow et al., 2014; Pender \& Brocchetto, 2011; Richardson, 2009; Säve-Söderbergh, 2010; von Wallis \& Klein, 2015; Watson, 2011). The most recent half decade (2015-2020) is characterized by research responding to the Paris agreement and the launch of the SDGs in 2015, with exponential growth in publications focusing on impact investing (Agrawal \& Hockerts, 2019, 2021; Caseau \& Grolleau, 2020; Lieberman, 2020; Robb \& Sattell, 2016; Viviani \& Maurel, 2019) innovative financial instruments such as social impact bonds (Carè et al., 2020; Giacomantonio, 2017; Rizzello \& Kabli, 2020; Torre, et al., 2019), and ESG investing and firm performance (Alessandrini \& Jondeau, 2020; Chen \& Mussalli, 2020; Giese et al., 2019; Landi \& Sciarelli, 2019; Schramade, 2016). The summary of the brief evolution of sustainable finance research is presented in Fig. 1, and will be investigated further in the later sections of this study.

Given the burgeoning research on sustainable finance, past researchers have also attempted to review the extant literature in the field. However, in most instances, such reviews were limited to a specific aspect of sustainable finance, and not sustainable finance as a whole. For example, using systematic reviews, researchers have consolidated the extant literature 


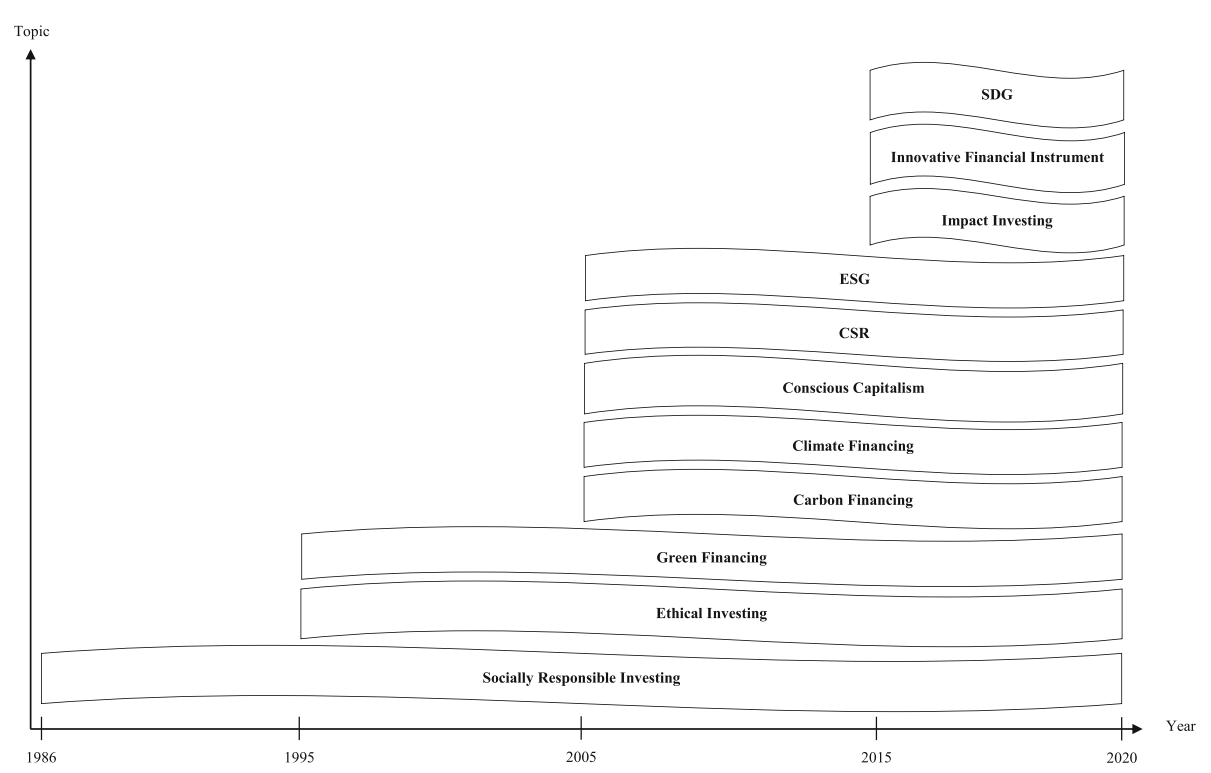

Fig. 1 Evolution of sustainable finance research. CSR Corporate social responsibility. ESG Environmental, social, and governance. SDG Sustainable development goals

pertaining to climate finance (Giglio et al., 2020), ESG (Daugaard, 2020; Widyawati, 2020), green finance (Malhotra \& Thakur, 2020; Zhang, et al., 2019), impact investing (Clarkin \& Cangioni, 2016), and socially responsible investing (Camilleri, 2020; Fabregat-Aibar et al., 2019; Rahman, et al., 2020; Revelli \& Viviani, 2015; Viviers \& Eccles, 2012), and using bibliometric analysis, researchers such as Bui et al. (2020) have revealed insights on sustainable corporate finance albeit from a small corpus of 227 articles. Apart from Cunha et al. (2021), which is the only and most recent review of sustainable finance prior to the present review, no other review has attempted to review the field as a whole. Yet, as mentioned previously, the review by Cunha et al. (2021) remains limited to a small corpus of 166 articles, and thus, providing a snapshot rather than a state-of-the-art overview of sustainable finance research, wherein the absence and need of the latter to provide a comprehensive stock take of the field motivates the present review, whose methodology will be disclosed in the next section.

\section{Methodology}

This study collects bibliometric data on sustainable finance research for its review. To do so, this study adopts and implements the Scientific Procedures and Rationales for Systematic Literature Reviews (SPAR-4-SLR) protocol, which consists of three major stages, namely assembling, arranging, and assessing of articles (Paul et al., 2021). The summary of the review procedure is illustrated in Fig. 2. 


\section{Assembling}

- Search Keywords: "carbon credit" OR "carbon finance" OR "carbon tax" OR "climate finance" OR "conscious capitalism" OR "ESG investing" OR "green bond" OR "green finance" OR "impact investing" OR "SDG financing" OR "socially responsible investing” OR "sustainability financing” OR "sustainability reporting" OR "sustainability risk disclosure" OR "sustainability risk management" OR "sustainable economy" OR "sustainable finance".

- Search Database: Scopus.

- Search Result: 10,850 documents.

\section{Arranging}

- Organizing Filters: Year, subject area, document type, publication stage, source type, and language.

- Filtered Year for Inclusion: Up to " $2020 "$.

- Filtered Subject Area for Inclusion: "Business, management, and accounting".

- Filtered Document Type for Inclusion: "Article".

- Filtered Publication Stage for Inclusion: "Final".

- Filtered Source Type for Inclusion: "Journal".

- Filtered Language for Inclusion: "English".

- Filtered Search Result: 936 articles.

\section{1}

\section{Assessing}

- Analysis Method: Bibliometric analysis techniques, namely:

- "performance analysis" (i.e., publication trend, most influential article and top contributing journal, author, institution, country, and methodological choice and research context) and

- "science mapping" via "temporary analysis using word clouds" (i.e., major topics) and "network analysis using keyword co-occurrence" (i.e., major themes) on 936 articles.

- Agenda Proposal Method: Reading of articles and reflection of extant gaps for each major theme.

- Reporting Convention: Figures, tables, and words.

- Limitation: Accuracy and completeness of bibliometric data from Scopus.

- Support: No funding received.

Fig. 2 Systematic review procedure using the SPAR-4-SLR protocol 


\subsection{Assembling}

To assemble the corpus of articles on sustainable finance, this study identified its search keywords relating to sustainable finance from the preliminary review of relevant literature in the previous section and consulted 10 experts to ascertain the suitability of those keywords to represent sustainable finance. This led to a combination of 17 keywords that can be organized into the following search string:

"carbon credit" OR "carbon finance" OR "carbon tax" OR "climate finance" OR "conscious capitalism" OR "ESG investing" OR "green bond" OR "green finance" OR "impact investing" OR "SDG financing" OR "socially responsible investing" OR "sustainability financing" OR "sustainability reporting" OR "sustainability risk disclosure" OR "sustainability risk management" OR "sustainable economy” OR "sustainable finance"

Following the identification of search keywords, this study conducted a search for articles using the aforementioned search string in the "article title, abstract, and keywords" on Scopus, which is the largest high-quality scientific database of scholarly articles (Comerio \& Strozzi, 2019; Norris \& Oppenheim, 2007), and thus chosen over its alternative, Web of Science, which contains less articles for review than Scopus (Paul et al., 2021). In total, 10,850 documents were returned from the search.

\subsection{Arranging}

To arrange the corpus of 10,850 articles returned from the assembling stage, this study used the category (code) function in Scopus to review the search results according to year, subject area, document type, publication stage, source type, and language, wherein search results were filtered and limited to "2020", "business, management, and accounting", "article", "final", "journal", and "English" in those categories, respectively. These filters were imposed in line with the recommendations of Paul et al. (2021) because 2020 represented the latest full year run; sustainable finance resides within business, management, and accounting; nonarticles such as editorials and notes may not be peer reviewed and the inclusion of reviews can lead to double-barreled insights; in-press articles were discarded as they have not been finalized; non-journal sources such as book, book chapter, and conference proceeding were excluded as they may not have undergone rigorous peer review; and non-English articles were not included on the basis of our limited language proficiency in languages other than English. This led to a reduced corpus consisting of 1,530 articles.

Following that, we downloaded and read each article, and eliminated another 594 articles that mentioned the search keywords sparingly. That is to say, the aspects of sustainable finance did not take center stage in the investigation of those articles, resulting in their removal. This led to a final corpus of 936 articles for review, which was confirmed following a random cross-check using other databases such as Google Scholar and publishers website such as Elsevier, Emerald, Sage, Springer, and Taylor and Francis to avoid unintended exclusion of relevant studies in the field (Goyal et al., 2021; Harari et al., 2020; Lim et al., 2021). 


\subsection{Assessing}

To assess the final corpus of 936 articles on sustainable finance, which is a relatively large corpus, this study adopts a bibliometric analysis approach for its review. In essence, a bibliometric analysis uses quantitative techniques to appraise scientific information of scholarly articles (Donthu et al., 2021a). Noteworthily, systematic reviews using bibliometrics are now a commonplace (Ellegaard \& Wallin, 2015), including business in general (Baker et al., 2020; Donthu et al., 2021a; Zupic \& Čater, 2015) and finance in particular (Durisin \& Puzone, 2009; Linnenluecke et al., 2018; Xu et al., 2018) as a bibliometric analysis can mitigate the potential bias that avail in manual (e.g., error prone) and qualitative (i.e., subjectivity) reviews using quantitative (i.e., objectivity) tools (Broadus, 1987; Burton et al., 2020), especially when the corpus for review is large (high hundreds to thousands of articles) (Donthu et al., 2021a), as in the case of the present review (i.e., 936 articles). Following past reviews (Cobo et al., 2011; Donthu et al., 2020, 2021d; Khan et al., 2021), this study performs a bibliometric analysis using a performance analysis to delinate the publication trend, the top articles and contributing journals, authors, institutions, and countries, and the methodological choices and research contexts, and a science mapping via a temporal analysis using word clouds (Bastian et al., 2009; van Eck \& Waltman, 2017) and a network analysis using keyword co-occurrence (Callon et al., 1983; Castriotta et al., 2019; Donthu et al., 2021a; Newman \& Girvan, 2004; Pesta et al., 2018) in VOSviewer (van Eck \& Waltman, 2017) to unpack the major themes and topics underpinning the intellectual structure of sustainable finance research. To advance insights in the field, this study curates a future research agenda based on our reading of the articles and reflection of extant gaps under each major theme. The next sections report the findings of the review, wherein narratives are supplemented by figures and tables.

\section{Findings}

\subsection{Performance analysis}

Performance analysis is a bibliometric analysis technique that describes the performance of a research domain (Donthu et al., 2021a), and in this case, the field of sustainable finance. This analysis is akin to that of the profiling of participants in empirical studies albeit in a more rigorous way through the use of bibliometric metrics (Donthu et al., 2021a). In this study, a performance analysis is conducted to reveal (1) the publication trend, (2) the most influential articles, the top contributing (3) journals, (4) authors, (5) institutions, and (6) countries, and (7) the methodological choices and research contexts of sustainable finance research.

\subsubsection{Publication trend for sustainable finance research}

The year-wise publication trend of sustainable finance research is presented in Fig. 3. The figure indicates that the first article on sustainable finance published in a journal indexed in Scopus appeared in 1986 (Ferris \& Rykaczewski, 1986), and that publications in the field have grown over the last 35 years (1986-2020). With only a single publication in 1986 and single-digit publications in each ensuing year up to 2006, the field of sustainable finance has proliferated considerably in the next 15 years, with a record high of 193 publications in 2020. Noteworthily, an exponential increase in publications is witnessed from 2015 onwards, which is the year when the Paris agreement and the SDGs were signed by United Nations 


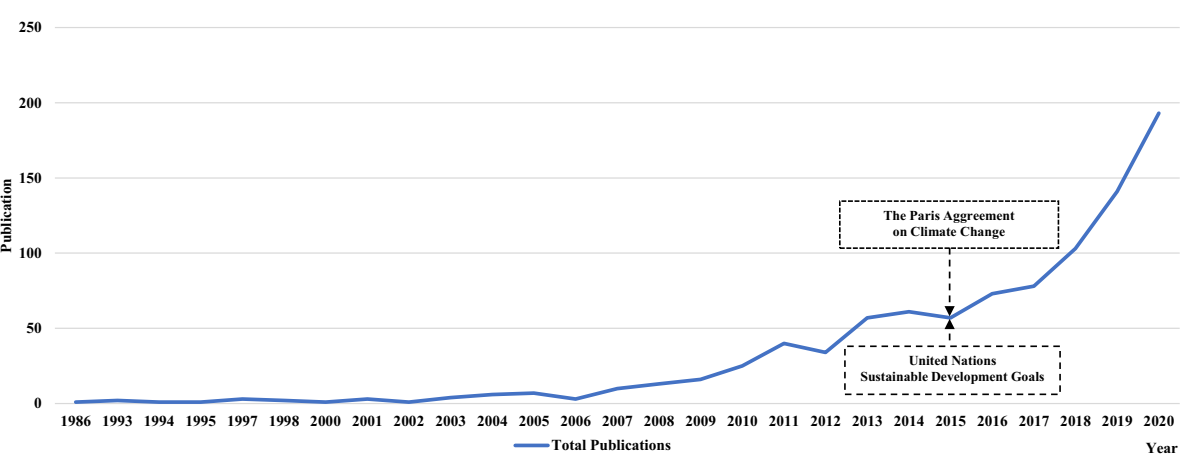

Fig. 3 Year-wise publication for sustainable finance research between 1986 and 2020

Member States. This is supported by a detailed scrutiny of the corpus, whereby close to $70 \%$ of articles were published between 2015 and 2020, thereby reaffirming 2015 as a landmark year for sustainable finance research.

\subsubsection{Most influential articles for sustainable finance research}

The most influential articles for sustainable finance research in terms of citations are presented in Table 1. The table indicates that Dedusenko's (2017) article is the most cited article in the field, with an average of 43.67 citations per year and a total of 655 citations since its publication in 2006. This is followed by Viviers, Ractliffe, and Hand's (2011) and Roundy's (2019) articles in Journal of Banking and Finance and Journal of Financial Economics, which have been cited 500 and 431 times, respectively. Interestingly, the top three most-cited articles in the field are about impact investing, which highlights its prominence influence in the field. Noteworthily, the top 25 most-cited articles in the field have amassed a total of 5970 citations, which reflects the significant influence that sustainable finance research has had in the scientific community.

\subsubsection{Top contributing journals for sustainable finance research}

The corpus of 936 articles on sustainable finance were published across 416 journals, with Table 2 indicating that the top 24 contributing journals with a minimum of five articles on sustainable finance have published 334 (35.68\%) articles in the field. Specifically, the top three most prolific journals are Sustainability, Journal of Business Ethics, and Journal of Sustainable Finance and Investment, with 52, 47, and 42 articles, respectively. However, in terms of influence, Journal of Business Ethics leads the pack with 2712 citations, followed by Journal of Banking and Finance and Climate Policy, with 1422 and 458 citations, respectively. Noteworthily, most of the top contributing journals have an impact factor above one and they are rated favorably ( 3 and 4) in the Academic Journal Guide by the Chartered Association of Business Schools, which indicates that sustainable finance as an area of research has received attention from some of the best journals in the field. 
Table 1 Most influential articles for sustainable finance research

\begin{tabular}{|c|c|c|c|c|c|}
\hline Author(s) & Article title & Source title & Year & $\mathrm{TC}$ & $\mathrm{C} / \mathrm{Y}$ \\
\hline Dedusenko E.A. & $\begin{array}{l}\text { Impact investing trends in } \\
\text { Russia and tourism }\end{array}$ & $\begin{array}{l}\text { Journal of Business } \\
\text { Ethics }\end{array}$ & 2006 & 655 & 43.67 \\
\hline $\begin{array}{l}\text { Viviers S., Ractliffe } \\
\text { T., Hand D. }\end{array}$ & $\begin{array}{l}\text { From philanthropy to impact } \\
\text { investing: Shifting mindsets } \\
\text { in South Africa }\end{array}$ & $\begin{array}{l}\text { Journal of Banking } \\
\text { and Finance }\end{array}$ & 2008 & 500 & 38.46 \\
\hline Roundy P.T. & $\begin{array}{l}\text { Regional differences in impact } \\
\text { investment: A theory of } \\
\text { impact investing ecosystems }\end{array}$ & $\begin{array}{l}\text { Journal of Financial } \\
\text { Economics }\end{array}$ & 2011 & 431 & 43.10 \\
\hline $\begin{array}{l}\text { Agrawal A., } \\
\text { Hockerts K. }\end{array}$ & $\begin{array}{l}\text { Impact investing strategy: } \\
\text { Managing conflicts between } \\
\text { impact investor and investee } \\
\text { social enterprise }\end{array}$ & $\begin{array}{l}\text { Journal of Banking } \\
\text { and Finance }\end{array}$ & 2011 & 383 & 38.30 \\
\hline $\begin{array}{l}\text { Lehner O.M., Harrer } \\
\text { T., Quast M. }\end{array}$ & $\begin{array}{l}\text { Building institutional } \\
\text { legitimacy in impact } \\
\text { investing: Strategies and } \\
\text { gaps in financial } \\
\text { communication and } \\
\text { discourse }\end{array}$ & $\begin{array}{l}\text { Financial Analysts } \\
\quad \text { Journal }\end{array}$ & 2005 & 354 & 22.13 \\
\hline $\begin{array}{l}\text { Kimbu A.N., } \\
\text { Tichaawa T.M. }\end{array}$ & $\begin{array}{l}\text { Determinants of impact } \\
\text { investing for tourism } \\
\text { development in emerging } \\
\text { destinations of sub-Saharan } \\
\text { Africa }\end{array}$ & $\begin{array}{l}\text { Financial Analysts } \\
\quad \text { Journal }\end{array}$ & 2000 & 340 & 16.19 \\
\hline $\begin{array}{l}\text { Lee M., Adbi A., } \\
\text { Singh J. }\end{array}$ & $\begin{array}{l}\text { Categorical cognition and } \\
\text { outcome efficiency in } \\
\text { impact investing decisions }\end{array}$ & $\begin{array}{l}\text { Journal of Financial } \\
\text { and Quantitative } \\
\text { Analysis }\end{array}$ & 2001 & 287 & 14.35 \\
\hline $\begin{array}{l}\text { Novak P.K., Amicis } \\
\text { L.D., Mozetič I. }\end{array}$ & $\begin{array}{l}\text { Impact investing market on } \\
\text { Twitter: Influential users } \\
\text { and communities }\end{array}$ & $\begin{array}{l}\text { Journal of Corporate } \\
\text { Finance }\end{array}$ & 2008 & 268 & 20.62 \\
\hline Jackson E.T. & $\begin{array}{l}\text { Interrogating the theory of } \\
\text { change: Evaluating impact } \\
\text { investing where it matters } \\
\text { most }\end{array}$ & $\begin{array}{l}\text { European Financial } \\
\text { Management }\end{array}$ & 2007 & 260 & 18.57 \\
\hline $\begin{array}{l}\text { Phillips S.D., } \\
\text { Johnson B. }\end{array}$ & $\begin{array}{l}\text { Inching to impact: The } \\
\text { demand side of social } \\
\text { impact investing }\end{array}$ & $\begin{array}{l}\text { Journal of Banking } \\
\text { and Finance }\end{array}$ & 2008 & 236 & 18.15 \\
\hline $\begin{array}{l}\text { Agrawal A., } \\
\text { Hockerts K. }\end{array}$ & $\begin{array}{l}\text { Impact investing: Review and } \\
\text { research agenda }\end{array}$ & $\begin{array}{l}\text { Journal of } \\
\text { Sustainable } \\
\text { Finance and } \\
\text { Investment }\end{array}$ & 2015 & 188 & 31.33 \\
\hline $\begin{array}{l}\text { Viviani J.-L., Maurel } \\
\text { C. }\end{array}$ & $\begin{array}{l}\text { Performance of impact } \\
\text { investing: A value creation } \\
\text { approach }\end{array}$ & $\begin{array}{l}\text { Journal of Business } \\
\text { Ethics }\end{array}$ & 2004 & 185 & 10.88 \\
\hline Jafri J. & $\begin{array}{l}\text { When billions meet trillions: } \\
\text { Impact investing and } \\
\text { shadow banking in Pakistan }\end{array}$ & $\begin{array}{l}\text { Business Strategy } \\
\text { and the } \\
\text { Environment }\end{array}$ & 2010 & 180 & 16.36 \\
\hline
\end{tabular}


Table 1 (continued)

\begin{tabular}{|c|c|c|c|c|c|}
\hline Author(s) & Article title & Source title & Year & $\mathrm{TC}$ & $\mathrm{C} / \mathrm{Y}$ \\
\hline $\begin{array}{l}\text { Höchstädter A.K., } \\
\text { Scheck B. }\end{array}$ & $\begin{array}{l}\text { What's in a name: An analysis } \\
\text { of impact investing } \\
\text { understandings by } \\
\text { academics and practitioners }\end{array}$ & $\begin{array}{l}\text { Journal of } \\
\text { Management }\end{array}$ & 2010 & 172 & 15.64 \\
\hline $\begin{array}{l}\text { Tekula R., Andersen } \\
\text { K. }\end{array}$ & $\begin{array}{l}\text { The role of government, } \\
\text { nonprofit, and private } \\
\text { facilitation of the impact } \\
\text { investing marketplace }\end{array}$ & $\begin{array}{l}\text { Accounting, } \\
\text { Organizations and } \\
\text { Society }\end{array}$ & 1993 & 172 & 6.14 \\
\hline $\begin{array}{l}\text { León T., Liern V., } \\
\text { Pérez-Gladish B. }\end{array}$ & $\begin{array}{l}\text { A multicriteria assessment } \\
\text { model for countries' degree } \\
\text { of preparedness for } \\
\text { successful impact investing }\end{array}$ & $\begin{array}{l}\text { Journal of Business } \\
\text { Ethics }\end{array}$ & 2007 & 159 & 11.36 \\
\hline Chen S., Harrison R. & $\begin{array}{l}\text { Beyond profit vs. purpose: } \\
\text { Transactional-relational } \\
\text { practices in impact investing }\end{array}$ & $\begin{array}{l}\text { Journal of } \\
\text { Management and } \\
\text { Governance }\end{array}$ & 2004 & 152 & 8.94 \\
\hline $\begin{array}{l}\text { Wood D., Thornley } \\
\text { B., Grace K. }\end{array}$ & $\begin{array}{l}\text { Institutional impact investing: } \\
\text { Practice and policy }\end{array}$ & $\begin{array}{l}\text { Journal of Financial } \\
\text { Research }\end{array}$ & 2005 & 151 & 9.44 \\
\hline $\begin{array}{l}\text { Kappen J., Mitchell } \\
\text { M., Chawla K. }\end{array}$ & $\begin{array}{l}\text { Institutionalizing social } \\
\text { impact investing: } \\
\text { Implications for Islamic } \\
\text { finance }\end{array}$ & $\begin{array}{l}\text { Journal of Financial } \\
\text { Economics }\end{array}$ & 2012 & 145 & 16.11 \\
\hline $\begin{array}{l}\text { Wong M.C.S., Yap } \\
\text { R.C.Y. }\end{array}$ & $\begin{array}{l}\text { Social impact investing for } \\
\text { marginalized communities } \\
\text { in Hong Kong: Cases and } \\
\text { issues }\end{array}$ & $\begin{array}{l}\text { Journal of Banking } \\
\text { and Finance }\end{array}$ & 2011 & 142 & 14.20 \\
\hline Jackson E.T. & $\begin{array}{l}\text { Evaluating social impact } \\
\text { bonds: Questions, } \\
\text { challenges, innovations, and } \\
\text { possibilities in measuring } \\
\text { outcomes in impact } \\
\text { investing }\end{array}$ & $\begin{array}{l}\text { Financial } \\
\quad \text { Management }\end{array}$ & 2012 & 130 & 14.44 \\
\hline $\begin{array}{l}\text { Mendell M., } \\
\text { Barbosa E. }\end{array}$ & $\begin{array}{l}\text { Impact investing: A } \\
\text { preliminary analysis of } \\
\text { emergent primary and } \\
\text { secondary exchange } \\
\text { platforms }\end{array}$ & $\begin{array}{l}\text { Journal of Business } \\
\text { Ethics }\end{array}$ & 2008 & 123 & 9.46 \\
\hline Espinosa S. & $\begin{array}{l}\text { From philanthropy to impact } \\
\text { investing: The case of } \\
\text { Luxembourg }\end{array}$ & Management Science & 2014 & 121 & 17.29 \\
\hline Urban B., George J. & $\begin{array}{l}\text { An empirical study on } \\
\text { measures relating to impact } \\
\text { investing in South Africa }\end{array}$ & $\begin{array}{l}\text { Journal of Business } \\
\text { Ethics }\end{array}$ & 2007 & 120 & 8.57 \\
\hline Lieberman D. & $\begin{array}{l}\text { Impact investing } 2.0 \text {-not just } \\
\text { for do-gooders anymore }\end{array}$ & $\begin{array}{l}\text { Journal of Business } \\
\text { Finance and } \\
\text { Accounting }\end{array}$ & 2007 & 116 & 8.29 \\
\hline
\end{tabular}

$T C$ Total citations, $C / Y$ Average citations per year 
Table 2 Top contributing journals for sustainable finance research

\begin{tabular}{|c|c|c|c|c|}
\hline Journal & $\mathrm{TP}$ & $\mathrm{TC}$ & AJG & IF \\
\hline Sustainability & 52 & 173 & NR & 3.251 \\
\hline Journal of Business Ethics & 47 & 2712 & 3 & 6.43 \\
\hline Journal of Sustainable Finance and Investment & 42 & 448 & 1 & 1.87 \\
\hline Climate Policy & 35 & 458 & NR & 5.085 \\
\hline Journal of Portfolio Management & 16 & 55 & 3 & 0.709 \\
\hline Ecological Economics & 11 & 233 & 3 & 5.389 \\
\hline Climate and Development & 11 & 125 & NR & 4.28 \\
\hline Journal of Banking and Finance & 10 & 1422 & 3 & 3.07 \\
\hline Finance Research Letters & 10 & 93 & 2 & 5.596 \\
\hline Journal of Cleaner Production & 9 & 54 & 2 & 9.297 \\
\hline Research in International Business and Finance & 8 & 96 & 2 & 4.091 \\
\hline World Development & 8 & 120 & 3 & 5.278 \\
\hline California Management Review & 8 & 76 & 3 & 8.836 \\
\hline Journal of Asset Management & 7 & 45 & 2 & 0.38 \\
\hline Organization and Environment & 7 & 41 & 3 & 6.116 \\
\hline Climatic Change & 7 & 55 & NR & 4.743 \\
\hline Social Responsibility Journal & 7 & 39 & 1 & 3.5 \\
\hline European Journal of Operational Research & 7 & 203 & 4 & 5.334 \\
\hline Global Environmental Change & 6 & 128 & 3 & 9.523 \\
\hline Corporate Social Responsibility and Environmental Management & 6 & 73 & 1 & 8.741 \\
\hline Business Strategy and the Environment & 5 & 246 & 3 & 10.302 \\
\hline Economic Modelling & 5 & 68 & 2 & 3.127 \\
\hline Global Policy & 5 & 34 & NR & 2.084 \\
\hline Energy Economics & 5 & 26 & 3 & 7.042 \\
\hline
\end{tabular}

TP Total publication, TC Total citation, AJG Academic Journal Guide (AJG) 2021 by Chartered Association of Business Schools (i.e., lowest rating 1/2/3/4/4* highest rating, $N R$ No rating). IF Impact factor from Journal Citation Report (JCR) 2020 by Web of Science (WOS)

\subsubsection{Top contributing authors for sustainable finance research}

The top contributing authors for sustainable finance research are presented in Table 3. The table indicates that Scholtens B. from University of Groningen, Netherlands and Cortez M.C. from University of Minho, Portugal are the two most prolific authors in the field with 10 articles each. This is followed by Richardson B.J. from University of British Columbia, United States and Dorfleitner G. from University of Regensburg, Germany with nine and eight articles, respectively. However, the most influential authors are S. Viviers from Stellenbosch University, South Africa and Hockerts K. from Copenhagen Business School, Denmark with 591 and 577 citations, respectively, though the latter $(\mathrm{TC} / \mathrm{TP}=144.28 ; \mathrm{TC} / \mathrm{TCP}=192.33)$ yields a better average return of citations each year than the former (TC/TP and TC/TCP $=$ 118.20). Taken collectively, the top 25 contributing authors for sustainable finance research have contributed a total of $132(14.10 \%)$ articles that have amassed 2127 citations in the field. 
Table 3 Top contributing authors for sustainable finance research

\begin{tabular}{|c|c|c|c|c|c|c|c|}
\hline Author & $\begin{array}{l}\text { Affiliation and } \\
\text { country }\end{array}$ & $\mathrm{TP}$ & $\mathrm{TCP}$ & $\mathrm{TC}$ & $\mathrm{TC} / \mathrm{TP}$ & $\mathrm{TC} / \mathrm{TCP}$ & $h$ \\
\hline Scholtens B. & $\begin{array}{l}\text { University of } \\
\text { Groningen, } \\
\text { Netherlands }\end{array}$ & 10 & 7 & 14 & 1.40 & 2.00 & 2 \\
\hline Cortez M.C. & $\begin{array}{l}\text { University of Minho, } \\
\text { Portugal }\end{array}$ & 10 & 7 & 11 & 1.10 & 1.57 & 1 \\
\hline Richardson B.J. & $\begin{array}{l}\text { University of } \\
\text { Tasmania, Australia }\end{array}$ & 9 & 6 & 48 & 5.33 & 8.00 & 2 \\
\hline Dorfleitner G. & $\begin{array}{l}\text { University of } \\
\text { Regensburg, } \\
\text { Germany }\end{array}$ & 8 & 6 & 20 & 2.50 & 3.33 & 3 \\
\hline Pauw P. & $\begin{array}{l}\text { German Development } \\
\text { Institute, Germany }\end{array}$ & 7 & 7 & 112 & 16.00 & 16.00 & 7 \\
\hline Taghizadeh-Hesary F. & $\begin{array}{l}\text { Tokai University, } \\
\text { Japan }\end{array}$ & 6 & 4 & 9 & 1.50 & 2.25 & 2 \\
\hline S. Viviers & $\begin{array}{l}\text { Stellenbosch } \\
\text { University, South } \\
\text { Africa }\end{array}$ & 5 & 5 & 591 & 118.20 & 118.20 & 4 \\
\hline J. Timmons Roberts & $\begin{array}{l}\text { Brown University, } \\
\text { USA }\end{array}$ & 5 & 5 & 84 & 16.80 & 16.80 & 5 \\
\hline Revelli C. & $\begin{array}{l}\text { Kedge Business } \\
\text { School, France }\end{array}$ & 5 & 5 & 13 & 2.60 & 2.60 & 2 \\
\hline Utz S. & $\begin{array}{l}\text { University of St. } \\
\text { Gallen, Switzerland }\end{array}$ & 5 & 5 & 10 & 2.00 & 2.00 & 2 \\
\hline C.Walkshaüsl & $\begin{array}{l}\text { University of } \\
\text { Regensburg, } \\
\text { Germany }\end{array}$ & 5 & 2 & 3 & 0.60 & 1.50 & 1 \\
\hline Derwall J. & $\begin{array}{l}\text { Maastricht University, } \\
\text { Netherlands }\end{array}$ & 5 & 2 & 2 & 0.40 & 1.00 & 1 \\
\hline Hockerts K. & $\begin{array}{l}\text { Copenhagen Business } \\
\text { School, Denmark }\end{array}$ & 4 & 3 & 577 & 144.25 & 192.33 & 3 \\
\hline Geobey S. & $\begin{array}{l}\text { University of } \\
\text { Waterloo, Canada }\end{array}$ & 4 & 4 & 143 & 35.75 & 35.75 & 3 \\
\hline Skovgaard J. & $\begin{array}{l}\text { Lund University, } \\
\text { Sweden }\end{array}$ & 4 & 4 & 109 & 27.25 & 27.25 & 4 \\
\hline Pickering J. & $\begin{array}{l}\text { University of } \\
\text { Canberra, Australia }\end{array}$ & 4 & 4 & 87 & 21.75 & 21.75 & 4 \\
\hline Michaelowa A. & $\begin{array}{l}\text { University of Zurich, } \\
\text { Switzerland }\end{array}$ & 4 & 4 & 82 & 20.50 & 20.50 & 4 \\
\hline Stadelmann M. & $\begin{array}{l}\text { University of Zurich, } \\
\text { Switzerland }\end{array}$ & 4 & 4 & 72 & 18.00 & 18.00 & 4 \\
\hline Urpelainen J. & $\begin{array}{l}\text { Johns Hopkins } \\
\text { University, USA }\end{array}$ & 4 & 4 & 59 & 14.75 & 14.75 & 4 \\
\hline
\end{tabular}


Table 3 (continued)

\begin{tabular}{|c|c|c|c|c|c|c|c|}
\hline Author & $\begin{array}{l}\text { Affiliation and } \\
\text { country }\end{array}$ & $\mathrm{TP}$ & TCP & $\mathrm{TC}$ & TC/TP & ТC/TCP & $h$ \\
\hline Hourcade J.C. & $\begin{array}{l}\text { Centre National de la } \\
\text { Recherche } \\
\text { Scientifique } \\
\text { (CNRS), France }\end{array}$ & 4 & 4 & 56 & 14.00 & 14.00 & 4 \\
\hline Nguyen M. & $\begin{array}{l}\text { University of } \\
\text { Regensburg, } \\
\text { Germany }\end{array}$ & 4 & 2 & 9 & 2.25 & 4.50 & 2 \\
\hline Yoshino N. & Keio University, Japan & 4 & 3 & 7 & 1.75 & 2.33 & 2 \\
\hline Silva F. & $\begin{array}{l}\text { University of Minho, } \\
\text { Portugal }\end{array}$ & 4 & 3 & 3 & 0.75 & 1.00 & 1 \\
\hline Kabir Hassan M. & $\begin{array}{l}\text { University of New } \\
\text { Orleans, USA }\end{array}$ & 4 & 2 & 3 & 0.75 & 1.50 & 1 \\
\hline Ter Horst J. & $\begin{array}{l}\text { Tilburg University, } \\
\text { Netherlands }\end{array}$ & 4 & 3 & 3 & 0.75 & 1.00 & 1 \\
\hline
\end{tabular}

TP Total publication, TCP Total cited publication, $T C$ Total citations, TC/TP Average citations per publication, TC/TCP Average citations per cited publication, $h h$-index

\subsubsection{Top contributing institutions for sustainable finance research}

The top contributing institutions for sustainable finance research are presented in Table 4. The table indicates that the most prolific institution in the field is University of Regensburg, Germany with 15 articles, followed by University of Oxford, United Kingdom with 13 articles, and University of British Columbia, Australia and University of California, United States with 12 articles each. However, the most influential institution is Tilburg University, the Netherlands with 1050 citations, followed by University of Mino, Portugal and Maastricht University, the Netherlands with 846 and 698 citations, respectively. Taken collectively, the top 25 contributing institutions for sustainable finance research have contributed a total of $211(22.54 \%)$ articles that have amassed 6439 citations in the field.

\subsubsection{Top contributing countries for sustainable finance research}

The top contributing countries for sustainable finance research are presented in Table 5. The table indicates that the most prolific country is the United States with 242 articles, followed by the United Kingdom and Germany with 131 and 90 articles, respectively. The United States and the United Kingdom also emerge as the top two most influential countries, with 4,986 and 2,799 citations, respectively, and they are joined by the Netherlands, which is the third most influential country with 2,194 citations. However, Portugal yields the highest average citation of 78.27 for the 13 articles that authors from the country have contributed to the field. While American and European countries dominate the list of the top 25 contributing countries, there is notable representation from African countries such as South Africa, Asian countries such as China and India, and Oceanic countries such as Australia. Despite this representation, only 71 out of 936 articles have drawn samples from African and Asian countries, which shows that the majority of research on sustainable finance continue to be America and Europe focused. Nonetheless, upon detailed scrutiny, we observe that sustainable finance research 
Table 4 Top contributing institutions for sustainable finance research

\begin{tabular}{|c|c|c|c|c|c|c|}
\hline Institution & $\mathrm{TP}$ & $\mathrm{TCP}$ & $\mathrm{TC}$ & $\mathrm{TC} / \mathrm{TP}$ & $\mathrm{TC} / \mathrm{TCP}$ & $h$ \\
\hline University of Regensburg & 15 & 15 & 264 & 17.60 & 17.60 & 9 \\
\hline University of Oxford & 13 & 11 & 264 & 20.31 & 24.00 & 7 \\
\hline University of British Columbia & 12 & 11 & 428 & 35.67 & 38.91 & 7 \\
\hline University of California & 12 & 11 & 381 & 31.75 & 34.64 & 6 \\
\hline University of Minho & 11 & 9 & 846 & 76.91 & 94.00 & 5 \\
\hline University of Groningen & 11 & 10 & 493 & 44.82 & 49.30 & 8 \\
\hline University of Zurich & 10 & 6 & 104 & 10.40 & 17.33 & 5 \\
\hline Tilburg University & 9 & 9 & 1050 & 116.67 & 116.67 & 6 \\
\hline Australian National University & 9 & 6 & 98 & 10.89 & 16.33 & 4 \\
\hline Griffith University & 9 & 7 & 86 & 9.56 & 12.29 & 4 \\
\hline German Development Institute & 8 & 6 & 89 & 11.13 & 14.83 & 5 \\
\hline Harvard University & 8 & 8 & 66 & 8.25 & 8.25 & 5 \\
\hline Columbia University & 8 & 8 & 34 & 4.25 & 4.25 & 4 \\
\hline Maastricht University & 7 & 6 & 698 & 99.71 & 116.33 & 5 \\
\hline York University & 7 & 6 & 517 & 73.86 & 86.17 & 5 \\
\hline University of Rome & 7 & 4 & 64 & 9.14 & 16.00 & 3 \\
\hline University of Cambridge & 7 & 4 & 16 & 2.29 & 4.00 & 2 \\
\hline Pennsylvania State University & 6 & 5 & 223 & 37.17 & 44.60 & 3 \\
\hline Stockholm Environment Institute & 6 & 5 & 142 & 23.67 & 28.40 & 5 \\
\hline Carleton University & 6 & 6 & 129 & 21.50 & 21.50 & 4 \\
\hline Brown University & 6 & 6 & 116 & 19.33 & 19.33 & 6 \\
\hline University of Waterloo & 6 & 4 & 102 & 17.00 & 25.50 & 4 \\
\hline Mercator Research Institute & 6 & 6 & 87 & 14.50 & 14.50 & 5 \\
\hline Potsdam Institute for Climate Impact Research & 6 & 6 & 79 & 13.17 & 13.17 & 5 \\
\hline University of Queensland & 6 & 5 & 63 & 10.50 & 12.60 & 4 \\
\hline
\end{tabular}

$\overline{T P}$ Total publication, $T C P$ Total cited publication, $T C$ Total citations, TC/TP Average citations per publication, TC/TCP Average citations per cited publication, $h h$-index

in African and Asian countries have begun to appear more prominently in the recent decade (2011-2020) (Fonta et al., 2018; Rajan et al., 2014; Urban \& George, 2018; Viviers et al., 2011), which should and will likely to continue in the future.

\subsubsection{Methodological choices and research contexts for sustainable finance research}

The methodological choices (i.e., research approach, research design, data collection technique, and data analysis tool) and research contexts (i.e., industry focus, research focus, and geographical focus) for sustainable finance research are presented in Table 6 across decades and over a cumulative period of 35 years (1986-2020).

Panel A of Table 6 depicts the preference of research approach for sustainable finance research. The qualitative approach tops the chart as the most preferred research approach across all decades, with $53 \%$ of articles in the field using this research approach. The quantitative approach is the next most preferred research approach, constituting $38 \%$ of articles, 
Table 5 Top contributing countries for sustainable finance research

\begin{tabular}{|c|c|c|c|c|c|c|}
\hline Country & $\mathrm{TP}$ & TCP & $\mathrm{TC}$ & $\mathrm{TC} / \mathrm{TP}$ & $\mathrm{TC} / \mathrm{TCP}$ & $h$ \\
\hline United States & 242 & 200 & 4986 & 20.60 & 24.93 & 35 \\
\hline United Kingdom & 131 & 105 & 2799 & 21.37 & 26.66 & 26 \\
\hline Germany & 90 & 76 & 1598 & 17.76 & 21.03 & 21 \\
\hline China & 74 & 42 & 247 & 3.34 & 5.88 & 10 \\
\hline Australia & 60 & 47 & 537 & 8.95 & 11.43 & 15 \\
\hline Canada & 58 & 53 & 1892 & 32.62 & 35.70 & 22 \\
\hline Italy & 45 & 32 & 260 & 5.78 & 8.13 & 9 \\
\hline Spain & 44 & 34 & 428 & 9.73 & 12.59 & 11 \\
\hline Netherlands & 43 & 36 & 2194 & 51.02 & 60.94 & 18 \\
\hline India & 39 & 26 & 229 & 5.87 & 8.81 & 9 \\
\hline France & 38 & 32 & 571 & 15.03 & 17.84 & 12 \\
\hline Switzerland & 31 & 24 & 306 & 9.87 & 12.75 & 10 \\
\hline South Africa & 30 & 19 & 161 & 5.37 & 8.47 & 7 \\
\hline Sweden & 24 & 19 & 476 & 19.83 & 25.05 & 11 \\
\hline Belgium & 20 & 16 & 447 & 22.35 & 27.94 & 8 \\
\hline Japan & 19 & 11 & 138 & 7.26 & 12.55 & 6 \\
\hline Malaysia & 19 & 13 & 63 & 3.32 & 4.85 & 4 \\
\hline Portugal & 13 & 11 & 861 & 66.23 & 78.27 & 6 \\
\hline Austria & 12 & 12 & 443 & 36.92 & 36.92 & 7 \\
\hline South Korea & 12 & 7 & 174 & 14.50 & 24.86 & 5 \\
\hline Finland & 8 & 5 & 131 & 16.38 & 26.20 & 4 \\
\hline Hong Kong & 8 & 6 & 40 & 5.00 & 6.67 & 3 \\
\hline Norway & 7 & 6 & 38 & 5.43 & 6.33 & 3 \\
\hline Saudi Arabia & 7 & 7 & 22 & 3.14 & 3.14 & 3 \\
\hline
\end{tabular}

$T P$ Total publication, $T C P$ Total cited publication, $T C$ Total citations, TC/TP Average citations per publication, $T C / T C P$ Average citations per cited publication, $h h$-index

whereas a mixed combination of the two approaches represents only $7.5 \%$ of articles in the corpus. Noteworthily, the share of the qualitative approach has been declining while the quantitative approach and the mixed approach have both gained increasing popularity over time, whereby the increased share of the quantitative approach being a reflection of the growing availability and accessibility of sustainable financial data, and the share of the mixed approach being a reflection of the increasing rigor required to publish sustainable finance research over time.

Panel B of Table 6 exhibits the preference of research design for sustainable finance research. The conceptual and empirical research designs were equally preferred in the field's early years (37.03\%), though a stronger preference for empirical research designs and a declining preference for conceptual research designs occur over time. There is also a notable increase in review research designs as time passes, which indicates the growing maturity of sustainable finance research given that reviews are a stock take of mature fields of research (Donthu et al., 2021a). The same observation applies for the mixed research design, which is another point to substantial our previous inference that the expectation of rigor in sustainable 
Table 6 Methodological choice and research context for sustainable finance research

\begin{tabular}{llllll}
\hline Panel and period & $\begin{array}{l}1986-1995 \\
(\%)\end{array}$ & $(\%)$ & $\begin{array}{l}1996-2005 \\
(\%)\end{array}$ & $\begin{array}{l}2016-2020 \\
(\%)\end{array}$ & $\begin{array}{l}\text { Overall } \\
(\%)\end{array}$ \\
\hline
\end{tabular}

Panel A: Research approach

Qualitative 60

Quantitative 40

59.25

57.59

51.02

53.53

Mixed

37.33

34.81

40.31

38.36

3.7

7.59

7.65

7.48

Panel B: Research design

$\begin{array}{ll}\text { Empirical } & 40 \\ \text { Conceptual } & 60 \\ \text { Review } & 0.00 \\ \text { Modelling } & 0.00 \\ \text { Mixed } & 0.00\end{array}$

37.03

40.82

48.13

45.30

37.03

28.16

21.60

24.47

3.70

7.91

8.33

14.81

4.75

8.84

9.51

Mixed

11.11

21.84

11.90

20.30

Panel C: Data collection technique

\begin{tabular}{|c|c|c|c|c|c|}
\hline Case study & 20 & 18.52 & 17.09 & 21.09 & 19.66 \\
\hline Interview & 40 & 11.11 & 21.20 & 24.83 & 23.29 \\
\hline Archival & 40 & 44.44 & 45.57 & 46.60 & 46.15 \\
\hline Survey & 0.00 & 3.70 & 10.13 & 8.84 & 9.08 \\
\hline Laboratory & 0.00 & 0.00 & 0.63 & 0.85 & 0.75 \\
\hline $\begin{array}{l}\text { No data } \\
\text { collected/reported }\end{array}$ & 0.00 & 18.52 & 20.25 & 9.01 & 13.03 \\
\hline \multicolumn{6}{|c|}{ Panel D: Data analysis technique } \\
\hline Descriptive & 0.00 & 22.22 & 26.27 & 29.93 & 28.31 \\
\hline Regression & 20 & 14.81 & 24.05 & 24.32 & 23.93 \\
\hline Other & 20 & 0 & 12.03 & 9.18 & 9.94 \\
\hline $\begin{array}{l}\text { No data analysis } \\
\text { conducted/reported }\end{array}$ & 60 & 62.9 & 37.66 & 36.90 & 38.03 \\
\hline \multicolumn{6}{|c|}{ Panel E: Industry focus } \\
\hline Services & 0.00 & 18.52 & 10.76 & 20.07 & 16.77 \\
\hline Manufacturing & 20 & 3.70 & 3.16 & 4.42 & 4.06 \\
\hline Both & 20 & 11.11 & 10.13 & 8.16 & 8.97 \\
\hline No specific industry & 60 & 59.26 & 75.95 & 67.35 & 69.98 \\
\hline \multicolumn{6}{|c|}{ Panel F: Research focus } \\
\hline Theory building & 0 & 0.00 & 0.00 & 0.34 & 0.21 \\
\hline Theory verification & 0 & 7.41 & 5.38 & 7.31 & 6.62 \\
\hline Application & 100 & 92.59 & 94.62 & 92.35 & 93.16 \\
\hline \multicolumn{6}{|c|}{ Panel G: Geographical focus } \\
\hline Single Country & 100 & 22.22 & 22.15 & 22.11 & 22.54 \\
\hline Multi Country & 0 & 11.11 & 6.01 & 12.07 & 9.94 \\
\hline Developing Country & 0 & 0.00 & 7.91 & 13.10 & 10.90 \\
\hline Developed Country & 100.00 & 100.00 & 92.09 & 86.90 & 89.10 \\
\hline
\end{tabular}


finance research has increased over time. Nonetheless, interest in modeling research designs fluctuate and continue to remain relatively small.

Panel C of Table 6 illustrates the preference of data collection techniques for sustainable finance research. Noteworthily, archival data is the most preferred data collection technique across all time periods (46.15\%), followed by interviews (23.29\%) and case studies (19.66\%). Surveys account for only $9.08 \%$, whereas laboratory data makes up for only $0.75 \%$ of the corpus, which indicates that sustainable finance research have plenty of room to grow using a quantitative approach predicated on primary data. The rest of the $13.03 \%$ of the corpus do not utilize any data as they are mainly conceptual articles.

Panel D of Table 6 indicates the preference of data analysis techniques for sustainable finance researcher. Descriptive (28.31\%) and regression $(23.93 \%)$ techniques appear to be most preferred, with a large majority of studies not employing any specific data analysis techniques $(38.03 \%)$. With regards to the former, we observe that research employing descriptive analysis typically offer basic descriptions of total, percentage, mean, median, and graphical representation of statistics, and advance descriptions using statistical analysis such as frequency analysis, $t$-test, and chi-square test, whereas research using regression analysis usually provide insights from ordinary least squares, logit, probit, panel, and vector-auto regression models. With regards to the latter, the nascent stage of sustainable finance in developing countries, which have yet to integrate sustainable finance in the economy and financial markets, could have led to a dearth of quantitative and statistical data for analysis, and thus, explaining why a large majority of studies do not employ any specific data analysis techniques. The rest of the $9.94 \%$ of the corpus have used other data analysis techniques such as CAPM modeling, Carhart modeling, data envelopment analysis, mathematical modeling, and variance-based techniques such as ANOVA, ANCOVA, MANOVA, and MANCOVA.

Panel E of Table 6 presents the industry focus of sustainable finance research. The panel indicates that research in the field have not been very focused to a specific industry as close to $70 \%$ of studies have not specified any industry of focus in their articles. Nonetheless, $30 \%$ of studies have adopted an industry focus, with services, especially financial services, being a highly popular industry due to the nature of sustainable finance $(16.77 \%)$. Only $4 \%$ of studies have shown a preference for manufacturing, with a special focus given to energy and allied sectors due to the concepts of carbon, climate, and green financing. The rest of the corpus $(9 \%)$ focus on both services and manufacturing, which have nonetheless been on a declining trend over time, indicating that the differences in each industry may be considerably challenging to be covered in a single study.

Panel F of Table 6 reveals the research focus of sustainable finance research in line with the classification by Gupta et al. (2009). The vast majority (93.2\%) of studies in the field have focused on the application of existing concepts in the real-world settings, with few studies building $(0.21 \%)$ and verifying $(6.62 \%)$ theories, which signals immense room for theory development and testing to theorize phenomena on sustainable finance beyond the limited re-use of traditional theories such as agency theory, institutional theory, legitimacy theory, modern portfolio theory, resource dependency theory, and stakeholder theory.

Finally, Panel G of Table 6 shows the geographical focus of sustainable finance research. Though most studies have not focused on any specific country $(67.52 \%)$, those studies that have are often seen focusing on a single country (22.54\%) as opposed to multiple countries $(9.94 \%)$, most of which are of a developed (89.10\%) rather than a developing (10.90\%) status. 


\subsection{Science mapping}

Science mapping is an analysis that uncovers and provides a graphical representation of what knowledge exist and how they are interrelated in a domain (Donthu et al., 2021a), and in this case, sustainable finance research. The science mapping of sustainable finance research is carried out using two bibliometric analysis techniques in VOSviewer, namely a temporal analysis using word clouds to unpack the major topics characterizing sustainable finance research across each time period, and a network analysis using keyword co-occurrence to reveal the major themes underpinning the intellectual structure of sustainable finance research over the last 35 years (1986-2020).

\subsubsection{Temporal analysis using word clouds for sustainable finance research}

The corpus of articles on sustainable finance research was segmented into four time periods: 1986 to 1995,1996 to 2005,2006 to 2015, and 2016 to 2020. The major topics in each time period uncovered through a temporal analysis are illustrated through the word clouds in Figs. 4, 5, 6 and 7.

Figure 4 depicts the advent of "socially" "responsible" "investing" in the initial years of sustainable finance research between 1986 and 1995, wherein aspects such as "activities", "beliefs", "costs", "personal" and "private" "portfolio", "reputation" "management",

Fig. 4 Sustainable finance research between 1986 and 1995

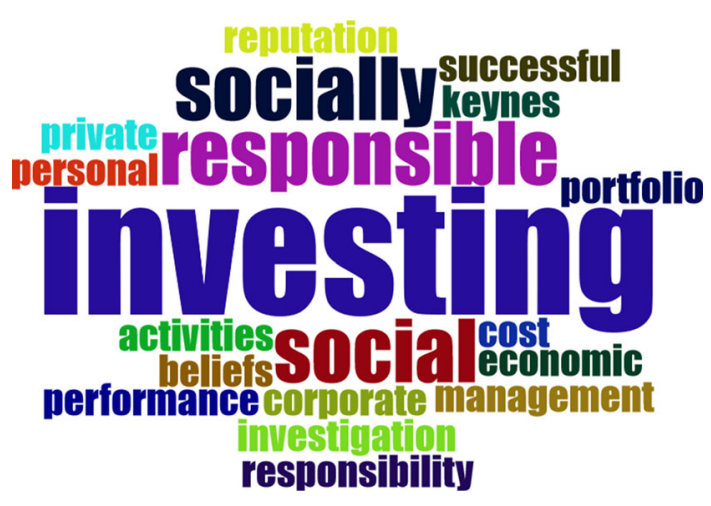

Fig. 5 Sustainable finance research between 1996 and 2005

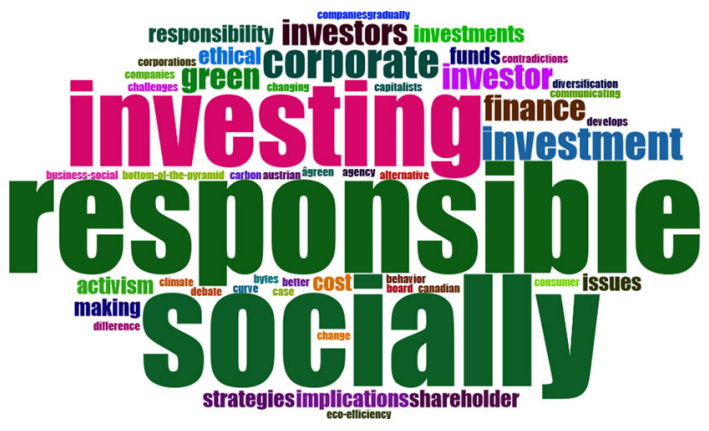


Fig. 6 Sustainable finance research between 2006 and 2015
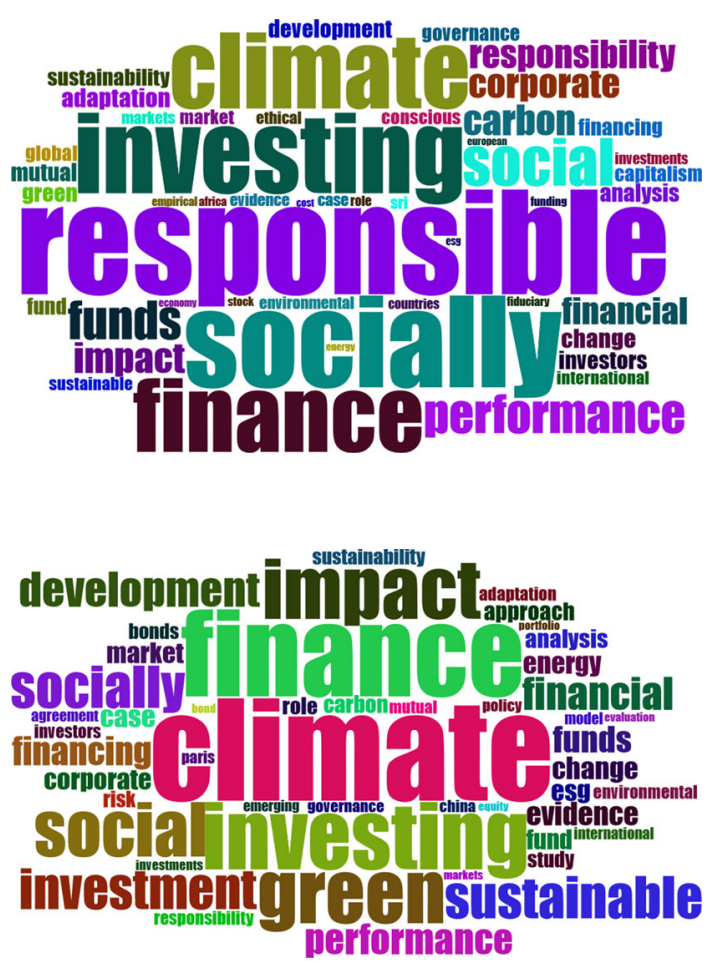

Fig. 7 Sustainable finance research between 2016 and 2020

and "successful" "performance" were explored, including the use of theories such as "Keynes"(ian) "economics" (Camey, 1994; Diltz, 1995; Ferris \& Rykaczewski, 1986; Herremans et al., 1993; Pierce, 1993).

Figure 5 exhibits the continued growth of "socially" "responsible" "investing" between 1996 to 2005 through the exploration of new areas that include "business-social" "activism", "agency", "challenges", "responsibility", and "strategies" for "communicating" and "making" a "difference" in "carbon", "climate", "ethical", and "green" "issues", the "funds" available for "investment, as well as the "implications" of this "alternative" "finance", "changing" "behavior", "debate", and "diversification" for the "board", "companies", "consumer", "corporations", "investor", and "shareholder". The field in this decade also "gradually" "develops" toward addressing "contradictions" among "capitalists" to create a "better" impact on the "bottom-of-the-pyramid" and "eco-efficiency", as well as finer-grained insights at the country level, such as those relating to "Austrian" and "Canadian" "companies".

Figure 6 illustrates the continued growth of "socially" "responsible" "investing" between 2006 and 2015, including the noteworthy proliferation of research that begun in the previous decade relating to "carbon" and "climate" "fund" and "stock", and the "case" or "evidence" of the "adaptation", "change", "impact", and "role" that such "investments" have for "sustainability" and "sustainable" "development". There is also ongoing research on "ethical" and "green" "funds" and their equivalent "costs", as well as a greater presence of "empirical" "analysis" and inclusion of the "global" "economy" and "international" "markets" such as "Africa" and the "European" "market". "Conscious" "capitalism" also emerges alongside "environmental", "social", and "governance" or "ESG" "fiduciary" and "mutual" "responsibility" among "corporate" "investors" and the aforementioned areas in this period (Halbritter 
\& Dorfleitner, 2015; Jackson, 2013a, 2013b; Mekonnen, 2014; Ryan, 2012; Viviers et al., 2011).

Finally, Fig. 7 indicates that "climate", "green", "impact", and "social" finance" and "investment" took center stage between 2016 and 2020 subsequent to the "Paris" agreement and the launch of the SDGs in 2015. Noteworthily, the "study" of sustainable finance in this five-year period has engaged and presented a "case" "analysis" and "evaluation" of the "bond", "equity", and "fund" "portfolio" manifested through the aforementioned sustainable finance concepts in tandem with the "adaptation", "agreement", "approach", "change", "governance", "model", "policy", and "risk" involved, as well as the corresponding "evidence" of the "role" and "impact" of such "investments" among "corporate" "investors" toward "ESG" "performance" and "sustainable" "development", including in "emerging" and "international" "markets" such as "energy" and "China", respectively.

\subsubsection{Network analysis}

Unlike the temporal analysis that employs word clouds and segments the corpus of articles on sustainable finance according to time periods to unpack the temporal evolution of topics in the field, the network analysis uses keyword co-occurrence on the entire corpus to unpack the major themes that characterize the intellectual structure of sustainable finance research since its inception in 1986 up to 2020. In this regard, the network analysis using keyword co-occurrence consolidates a wide range of topics according to thematic similarity, thereby shedding light on the major themes (or knowledge departments) in the field of sustainable finance. The major themes that emerged from the keyword co-occurrences in the network analysis of the entire corpus generated through VOSviewer are illustrated in Fig. 8, whereas the accompanying descriptive is presented in Table 7 and the interrelatedness between themes is reported in Table 8 .

In total, the results of the network analysis of keyword co-occurrence presented in Fig. 8 and Table 7 reveal eight major themes pertaining to sustainable finance, namely socially

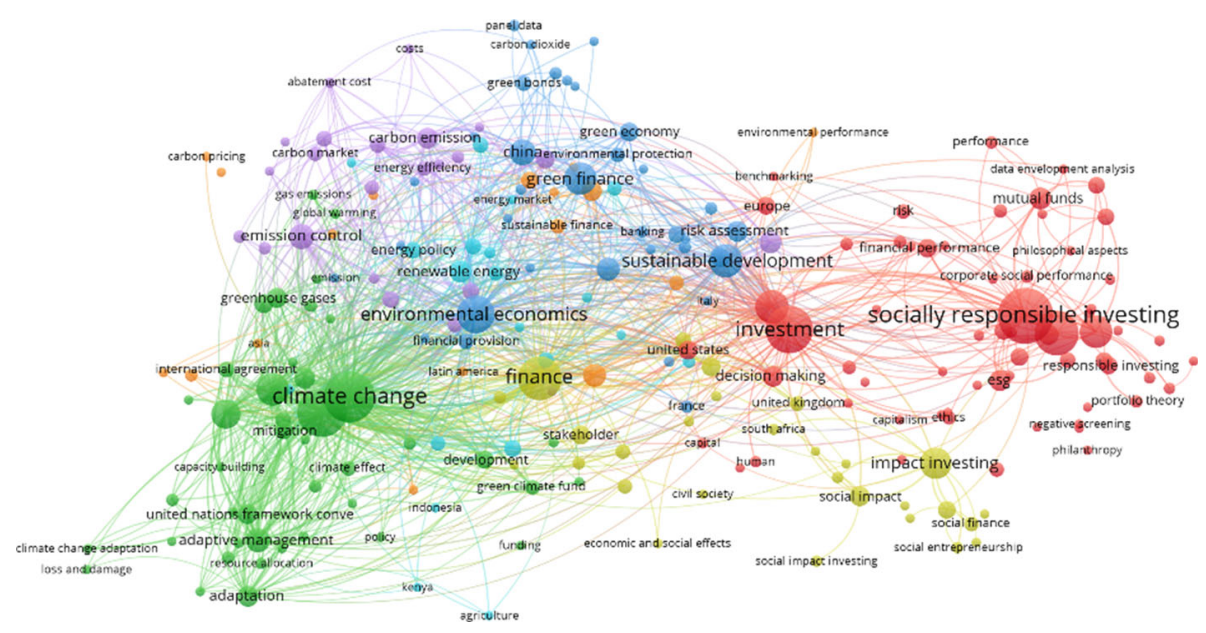

Fig. 8 Keyword network of sustainable finance research. Red = socially responsible investing. Green $=$ climate financing. Dark blue $=$ green financing. Yellow $=$ impact investing. Purple $=$ carbon financing. Light blue $=$ energy financing. Orange $=$ governance of sustainable financing and investing. (Color figure online) 
Table 7 Major clusters and keywords for sustainable finance research

\begin{tabular}{|c|c|c|c|c|c|c|c|}
\hline Keyword & TO & DC & $\mathrm{EC}$ & Keyword & TO & $\mathrm{DC}$ & $\mathrm{EC}$ \\
\hline \multicolumn{4}{|c|}{ Cluster 1: Socially responsible investing } & \multicolumn{4}{|l|}{ Cluster 2: Climate financing } \\
\hline $\begin{array}{l}\text { Socially responsible } \\
\text { investing }\end{array}$ & 175 & 120 & 0.59 & Climate change & 150 & 166 & 0.92 \\
\hline Investment & 127 & 178 & 0.93 & Climate finance & 140 & 157 & 0.88 \\
\hline $\begin{array}{l}\text { Corporate social } \\
\text { responsibility }\end{array}$ & 110 & 94 & 0.47 & Environmental policy & 59 & 126 & 0.77 \\
\hline Sustainability & 65 & 147 & 0.81 & Developing world & 49 & 110 & 0.68 \\
\hline $\begin{array}{l}\text { Socially responsible } \\
\text { investment }\end{array}$ & 61 & 76 & 0.37 & Adaptive management & 34 & 91 & 0.58 \\
\hline Mutual funds & 27 & 48 & 0.30 & Adaptation & 26 & 66 & 0.42 \\
\hline Decision making & 25 & 100 & 0.62 & Developing Countries & 25 & 82 & 0.54 \\
\hline ESG & 25 & 47 & 0.23 & $\begin{array}{l}\text { United Nations Framework } \\
\text { Convention on Climate } \\
\text { Change }\end{array}$ & 24 & 72 & 0.48 \\
\hline $\begin{array}{l}\text { Corporate } \\
\text { governance }\end{array}$ & 23 & 34 & 0.19 & Greenhouse gases & 23 & 83 & 0.58 \\
\hline $\begin{array}{l}\text { Financial } \\
\text { performance }\end{array}$ & 21 & 65 & 0.40 & Paris agreement & 21 & 54 & 0.38 \\
\hline \multicolumn{4}{|c|}{ Cluster 3: Green financing } & \multicolumn{4}{|l|}{ Cluster 4: Impact investing } \\
\hline $\begin{array}{l}\text { Environmental } \\
\text { economics }\end{array}$ & 82 & 165 & 0.94 & Finance & 110 & 188 & 1.00 \\
\hline $\begin{array}{l}\text { Sustainable } \\
\text { development }\end{array}$ & 64 & 143 & 0.80 & Impact Investing & 56 & 69 & 0.35 \\
\hline Green finance & 60 & 95 & 0.60 & Social Impact & 22 & 55 & 0.31 \\
\hline China & 39 & 98 & 0.63 & Innovation & 21 & 85 & 0.53 \\
\hline Financial system & 32 & 02 & 0.66 & Stakeholder & 20 & 67 & 0.41 \\
\hline Risk assessment & 26 & 87 & 0.56 & Social Enterprise & 18 & 30 & 0.18 \\
\hline Green economics & 21 & 69 & 0.48 & Strategic Approach & 14 & 65 & 0.45 \\
\hline $\begin{array}{l}\text { Sustainable } \\
\text { development goals }\end{array}$ & 21 & 69 & 0.45 & United Kingdom & 13 & 63 & 0.39 \\
\hline Market conditions & 16 & 64 & 0.43 & India & 12 & 57 & 0.36 \\
\hline Financial provisions & 14 & 69 & 0.43 & Political Economy & 12 & 39 & 0.29 \\
\hline \multicolumn{4}{|c|}{ Cluster 5: Carbon financing } & \multicolumn{4}{|l|}{ Cluster 6: Energy financing } \\
\hline Emission control & 36 & 102 & 0.65 & Renewable Energy & 27 & 79 & 0.54 \\
\hline Financial market & 28 & 89 & 0.56 & Private Sector & 17 & 76 & 0.50 \\
\hline Carbon emission & 25 & 89 & 0.59 & Energy Policy & 17 & 68 & 0.50 \\
\hline Commerce & 20 & 85 & 0.57 & Alternative Energy & 15 & 82 & 0.58 \\
\hline $\begin{array}{l}\text { Clean development } \\
\text { mechanism }\end{array}$ & 17 & 58 & 0.42 & Financial Services & 15 & 70 & 0.49 \\
\hline Carbon finance & 16 & 54 & 0.40 & Fossil Fuel & 14 & 65 & 0.49 \\
\hline Carbon & 15 & 78 & 0.55 & Economic Growth & 13 & 65 & 0.49 \\
\hline
\end{tabular}


Table 7 (continued)

\begin{tabular}{|c|c|c|c|c|c|c|c|}
\hline Keyword & TO & $\mathrm{DC}$ & $\mathrm{EC}$ & Keyword & TO & $\mathrm{DC}$ & $\mathrm{EC}$ \\
\hline Emissions trading & 15 & 60 & 0.43 & Africa & 13 & 48 & 0.34 \\
\hline Empirical analysis & 13 & 71 & 0.49 & Environmental Impact & 12 & 71 & 0.52 \\
\hline Energy efficiency & 13 & 62 & 0.45 & Investment Incentive & 10 & 57 & 0.39 \\
\hline \multicolumn{8}{|c|}{$\begin{array}{l}\text { Cluster 7: Governance of sustainable } \\
\text { financing and investing }\end{array}$} \\
\hline $\begin{array}{l}\text { Governance } \\
\text { approach }\end{array}$ & 30 & 108 & 0.67 & & & & \\
\hline Economics & 23 & 88 & 0.59 & & & & \\
\hline $\begin{array}{l}\text { Economic } \\
\text { development }\end{array}$ & 17 & 84 & 0.57 & & & & \\
\hline $\begin{array}{r}\text { Environmental } \\
\text { management }\end{array}$ & 13 & 63 & 0.45 & & & & \\
\hline Sustainable finance & 12 & 31 & 0.23 & & & & \\
\hline Redd + & 10 & 32 & 0.24 & & & & \\
\hline Japan & 6 & 44 & 0.34 & & & & \\
\hline $\begin{array}{l}\text { Environmental } \\
\text { planning }\end{array}$ & 6 & 33 & 0.26 & & & & \\
\hline $\begin{array}{c}\text { Environmental } \\
\text { performance }\end{array}$ & 6 & 32 & 0.26 & & & & \\
\hline Latin America & 6 & 28 & 0.23 & & & & \\
\hline
\end{tabular}

TO Total occurrence, DC Degree of centrality, EC Eigenvector centrality, Top keywords with TO $\geq 6$ are presented for each cluster. Cluster $=$ theme. Keyword $=$ topic

Table 8 Cluster-to-cluster links and cluster summary of sustainable finance research

\begin{tabular}{llllllrr}
\hline From/To & $\begin{array}{l}\text { Cluster 1 } \\
(\%)\end{array}$ & $\begin{array}{l}\text { Cluster 2 } \\
(\%)\end{array}$ & $\begin{array}{l}\text { Cluster 3 } \\
(\%)\end{array}$ & $\begin{array}{l}\text { Cluster 4 } \\
(\%)\end{array}$ & $\begin{array}{l}\text { Cluster 5 } \\
(\%)\end{array}$ & $\begin{array}{l}\text { Cluster 6 } \\
(\%)\end{array}$ & $\begin{array}{l}\text { Cluster 7 } \\
(\%)\end{array}$ \\
\hline Cluster 1 & $\mathbf{4 7 . 1 2}$ & 9.89 & 13.71 & 10.38 & 7.05 & 6.65 & 5.19 \\
Cluster 2 & 9.97 & $\mathbf{3 9 . 3 4}$ & 13.23 & 8.90 & 11.13 & 10.82 & 6.62 \\
Cluster 3 & 16.66 & 15.96 & $\mathbf{2 8 . 8 9}$ & 10.35 & 12.24 & 8.68 & 7.22 \\
Cluster 4 & 19.58 & 16.65 & 16.07 & $\mathbf{2 7 . 7 8}$ & 8.28 & 6.53 & 5.10 \\
Cluster 5 & 12.48 & 19.54 & 17.82 & 7.77 & $\mathbf{2 5 . 9 0}$ & 9.97 & 6.51 \\
Cluster 6 & 14.56 & 23.50 & 15.63 & 7.57 & 12.33 & $\mathbf{2 1 . 9 4}$ & 4.47 \\
Cluster 7 & 16.79 & 21.23 & 19.23 & 8.75 & 11.91 & 6.60 & $\mathbf{1 5 . 4 9}$ \\
\% K & 28.14 & 18.61 & 15.15 & 12.12 & 9.96 & 8.66 & 7.36 \\
\%L & 42.75 & 42.43 & 35.19 & 22.67 & 24.17 & 19.54 & 13.22 \\
\hline
\end{tabular}

$\% \mathrm{~K}=$ Percentage of total keywords in the network stemming from each cluster. $\% \mathrm{~L}=$ Percentage of total links (within and across clusters) in the network related to each cluster. The figures in bold represent the percentage of total links in the network within each cluster. Cluster $1=$ socially responsible investing. Cluster $2=$ climate financing. Cluster $3=$ green financing. Cluster $4=$ impact investing. Cluster $5=$ carbon financing. Cluster 6 $=$ energy financing. Cluster $7=$ governance of sustainable financing and investing 
responsible investing (first and red cluster), climate financing (second and green cluster), green financing (third and dark blue cluster), impact investing (fourth and yellow cluster), carbon financing (fifth and purple cluster), energy financing (sixth and light blue cluster), and governance of sustainable financing and investing (seventh and orange cluster).

The accompanying metrics in Table 7 shed light on the total occurrence (TO) of each keyword or topic, the degree of centrality (DC) measuring the number of connections for each keyword or topic, and the eigenvector centrality (EC) measuring the relative importance of each keyword or topic in terms of its connection to other keywords or topics, wherein keywords or topics with a high number of connections that are also connected to other keywords or topics with such characteristics will receive a higher EC score (Donthu et al., 2021a).

The nature of interrelatedness of each major theme is reported in Table 8, wherein twoway contributions are observed, though the contributions of one way may be notably more than the other way. For example, the table indicates that impact investing (fourth cluster) contributes $19.58 \%$ to socially responsible investing (first cluster), whereas the contribution of the opposite is $10.38 \%$. Similarly, the table indicates that energy financing (sixth cluster) and governance of sustainable financing and investing (seventh cluster) contribute $23.50 \%$ and $21.23 \%$ to climate financing (second cluster), whereas the contributions of the opposite are $10.82 \%$ and $6.62 \%$, respectively. Noteworthily, each keyword or topic can be primarily assigned to a major theme or cluster (Total $\% \mathrm{~K}=100 \%$ ), though their links (relationships) can span across themes or clusters (Total $\% \mathrm{~L}>100 \%$ ), thereby reflecting both the disciplinary and interdisciplinary nature of research on sustainable finance. The summaries of each major theme or cluster are presented next.

Cluster 1 (red): socially responsible investing The largest cluster pertains to socially responsible investing, comprising $28.14 \%$ of total keywords and $42.75 \%$ of total links in the network of sustainable finance research. The most popular keyword or topic in this cluster is "socially responsible investing", which appears in 175 articles and is connected to another 120 keywords. Other popular keywords or topics in this cluster that are researched in conjunction with socially responsible investing include "investment", "corporate social responsibility", "sustainability", "socially responsible investment", "mutual funds", "decision making", "ESG", "corporate governance", and "financial performance". Under this cluster, researchers have explained the performance of socially responsible funds and their outperformance over regular mutual funds (Jafri, 2019), the ethical requirements to fulfill social responsible investing (von Wallis \& Klein, 2015), and how ESG scores can enhance investment decision making (Chow et al., 2014), among others.

Cluster 2 (green): climate financing The second largest cluster relates to climate financing, consisting of $18.61 \%$ of total keywords and $42.43 \%$ of total links in the network of sustainable finance research. The most popular keyword or topic on climate financing is "climate change", which appears in 150 articles and is connected to another 166 keywords or topics. Other popular keywords or topics in this cluster that are researched in conjunction with climate financing include "environmental policy", "developing world", "adaptive management", the "United Nations Framework Convention on Climate Change", "greenhouse gases" and the "Paris Agreement". Under this cluster, researchers have focused on the effects of climate change and the need for climate financing to mitigate greenhouse gases contributing to climate change in line with transnational agreements and frameworks (Dam \& Scholtens, 2015; Gutiérrez \& Gutiérrez, 2019; Ibrahim et al., 2016; Skovgaard, 2015), among others. 
Cluster 3 (dark blue): green financing The third largest cluster pertains to green financing, containing $15.15 \%$ of total keywords and $35.19 \%$ of total links in the network of sustainable finance research. The most popular keyword or topic on green financing is "environmental economics", which appears in 82 articles and is connected to another 165 keywords. Other popular keywords or topics in this cluster that are researched in conjunction with green financing include "sustainable development", "China", "financial system", "risk assessment", "green economies", "sustainable development goals", "market conditions", and "financial provisions". Under this cluster, researchers have highlighted the promise of environmental protection through green finance and policies (Tan et al., 2017), as well as the contributions of green bonds and hybrid innovative instruments toward achieving the sustainable development goals (Alessandrini \& Jondeau, 2020; Muhamat et al., 2017; Vazquez \& Chin, 2019), among others.

Cluster 4 (yellow): impact investing The fourth largest cluster relates to impact investing, encapsulating $12.12 \%$ of total keywords and $22.67 \%$ of total links in the network of sustainable finance research. The most popular keyword or topic in this cluster is "finance", which appears in 110 articles and is connected to another 188 keywords, followed by "impact investing", which appears in 56 articles and is connected to another 69 keywords. Other popular keywords or topics in this cluster that are researched in conjunction with impact investing include "social impact", "innovation", "stakeholder", "social enterprise", "strategic approach", "United Kingdom", "India", and "political economy". Under this cluster researchers have demonstrated how social enterprises and social entrepreneurship engage in social impact investments and innovations through social impact bonds and hybrid instruments (Abadie et al., 2013; Richardson, 2014; Roehrer \& Kouadio, 2015), as well as business models for sustainability for impact investing and social impact bonds (Malhotra \& Thakur, 2020), among others.

Cluster 5 (purple): carbon financing The fifth largest cluster pertains to carbon financing, including $9.96 \%$ of total keywords and $24.17 \%$ of total links in the network of sustainable finance research. The most popular keyword or topic on carbon financing is "emission control", which appears in 36 articles and is connected to another 102 keywords or topics. Other popular keywords or topics in the cluster that are researched in conjunction with carbon financing include "financial market", "carbon emission", "commerce", "clean development mechanism", "carbon", "emissions trading", "empirical analysis", and "energy efficiency". Under this cluster, researchers discuss the feasibility and implementation of carbon finance (Pinsky et al., 2019), the carbon market crisis and clean development mechanism required for adapting funds and emissions trading (Harmeling \& Kaloga, 2011) in international markets (Lesser et al., 2014), and the societal perceptions of socially responsible financing, including that emerging from carbon financing, for sustainable development (Escrig-Olmedo et al., 2013), among others.

Cluster 6 (light blue): energy financing The sixth largest cluster relates to energy financing, which is made up of $8.66 \%$ of total keywords and $19.54 \%$ of total links in the network of sustainable finance research. The most popular keyword or topic on energy financing is "renewable energy", which appears in 27 articles and is connected to another 79 keywords. Other important keywords or topics in the cluster that are researched in conjunction with energy financing include "private sector", "energy policy", "alternative energy", "financial services", "fossil fuel", "economic growth", "Africa", "environmental impact", and "investment incentive". Under this cluster, researchers have shed light on impact investment options 
that include energy finance focusing on alternative and renewable energy (Geobey \& Callahan, 2017; Marti, 2013), including in developing economies such as the Middle East (Sisodia et al., 2020), among others.

Cluster 7 (orange): governance of sustainable financing and investing The seventh largest cluster pertains to governance of sustainable financing and investing, which represents $7.36 \%$ of total keywords and $13.22 \%$ of total links in the network of sustainable finance research. The most popular keyword or topic in this cluster is "governance approach", which appears in 30 articles and is connected to another 108 keywords. Other important keywords or topics in the cluster that are researched in conjunction with governance of sustainable financing and investing include "economics", "economic development", "environmental management", "Redd+", "Japan", "environmental planning", "environmental performance", and "Latin America". Under this cluster, researchers have focused on the alignment of global financial markets with the Paris agreement (Thomä et al., 2019), economic development through sustainable finance (Pinsky et al., 2020), and sustainable financing instruments for sustainable development (Zhang et al., 2020). For example, Thomä et al. (2019) explored a common set of accounting principles to be utilized for the alignment of equity and bond asset classes and multiple stakeholders towards the Paris agreement, whereas Pinsky et al. (2020) shed light on the governance process of REDD+ and performance-based mechanisms to incentive developing countries to engage in sustainable finance.

\section{Forging the way forward}

Sustainable finance has been and will continue to remain relevant for business schools, financial institutions, financial markets, and regulators. Noteworthily, both developed and developing countries are increasingly seen to be mandating SDG attainments through sustainable finance such as carbon, climate, and green financing (Dikau \& Volz, 2021; Elavarasan et al., 2021; Taghizadeh-Hesary \& Yoshino, 2019), whose importance are likely to magnify post the COVID-19 pandemic because of the setbacks that the pandemic has inflicted on the world's progress toward the agenda of greater sustainability (United Nations, 2021). Besides that, financial markets are always on the lookout for innovative sustainable finance instruments that they can opportunistically leverage to meet economic demands whilst making impactful contributions toward sustainability and sustainable development, especially with regards to the attainment of the SDGs and the reduction of carbon footprint in accordance with the Paris agreement (Muganyi et al., 2021; Yu et al., 2021). Similarly, investors today are showing greater interest in ESG and socially responsible investment funds, giving directives to fund managers to screen and pursue funds for impact investing (Alda, 2020, 2021; Chen et al., 2021; Joliet \& Titova, 2018; Yesuf \& Aassouli, 2020). Taken collectively, a continuous stream of new insights is thus required to ignite and satisfy evolving demands for sustainable finance.

With the growth in the body of knowledge and the availability of data on transactions specific to sustainable finance, future researchers can expect to be in a much more privilege position as compared to past researchers when they examine the direct and indirect causes and effects of myriad aspects of sustainable finance, especially in terms of its performance and return (Chen \& Ma, 2021; Kling et al., 2021; Tian \& Lin, 2019; Yao et al., 2021; Zhang, 2021). Indeed, the growing interest in sustainable finance has been evidenced in this review through the notable increase in the number of related research articles over the years, as well 
as the increased participation of investors and regulators in the field (Li et al., 2020; Schulz et al., 2020). More importantly, our reading of the articles and reflection of extant gaps under each major theme have led to several suggestions that should pave the way forward for future research to pollinate the field of sustainable finance in meaningful ways. Specifically, we observe that the major themes in the existing corpus have largely focused on the different types of sustainable finance (e.g., socially responsible investing, climate financing, green financing, impact investing, carbon financing, and energy financing), with the theme of governance being the noteworthy exception. While concepts such as green financing, carbon financing, and energy financing appear to be relatively similar at first glance, they can be differentiated through their research focus: green financing concentrates on increasing the financial flow (e.g., banking, micro-credit, insurance, and investment) across sectors (e.g., public, private, and not-for-profit) to sustainable development priorities more broadly, whereas carbon and energy financing focus on doing the same but for sustainable development priorities specific to carbon emission (e.g., greenhouse effects) and energy (e.g., renewable energy), respectively. We also realize that the major themes are interrelated and can therefore affect one another. In light of our learning of the field's composition and trajectory, we have deliberately decided to curate a future research agenda based on our reflection of the commonalities in the extant gaps and future research directions that we found from literature published within the last five years (2016-2020) that remain relatively underexplored, a summary of which we present in Table 9 and discuss in the next sections.

\subsection{Developing and diffusing innovative sustainable financing instruments}

The necessity for innovative financing instruments that can mobilize funds toward sustainable development has increased for both developed and developing economies as a result of the COVID-19 pandemic, an unprecedented global catastrophe that has reversed much of the world's progress in sustainability (United Nations, 2021). Though many researchers are addressing this need through studies on socially responsible investing, climate financing, green financing, impact investing, carbon financing, and energy financing, most results remain inconclusive as the field continues to provide limited insights on broad range of financial markets, especially emerging financial markets other than China (Ari \& Koc, 2021; Sinha et al., 2021). Some researchers have reasoned that funding for sustainable finance and sustainable development continues to be developing, and thus, more empirical evidence in both established and emerging markets is needed (Clark et al., 2018). Noteworthily, venture capital investments play a pivotal role to propel innovation in sustainable financing and impact investing given the magnitude of funds that they make available, as seen through financial markets such as China, where government interventions and market forces have encouraged such investments in ways that lead to cleaner and sustainable environments (Chen et al., 2021). Moreover, the issuance of innovative sustainable financing instruments can assist firms in attaining stock liquidity (e.g., the issuance of green bonds affects stock prices positively), yet limited issuance of such instruments exist in emerging financial markets such as India (Tang \& Zhang, 2020). More importantly, innovative sustainable financing instruments can only become popular in financial markets if they are supported by formal and information institutions as they play an important role to increase its supply as well as consumer and corporate investors' awareness, understanding, and demand of the benefits and costs of such financing and investing options in financial markets (Cui et al., 2020). Therefore, we propose five research questions to enrich understanding and prescription of innovative sustainable 


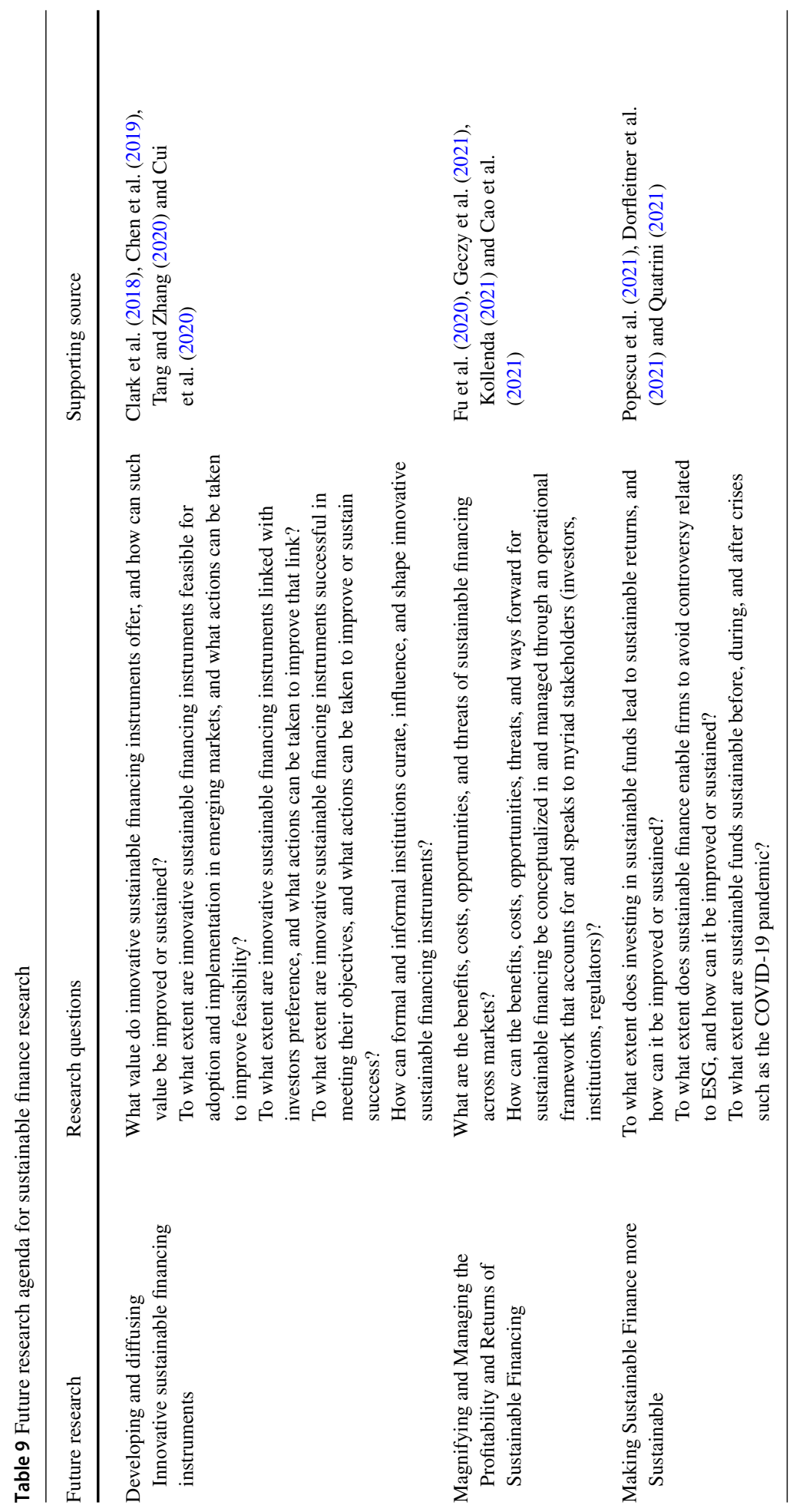




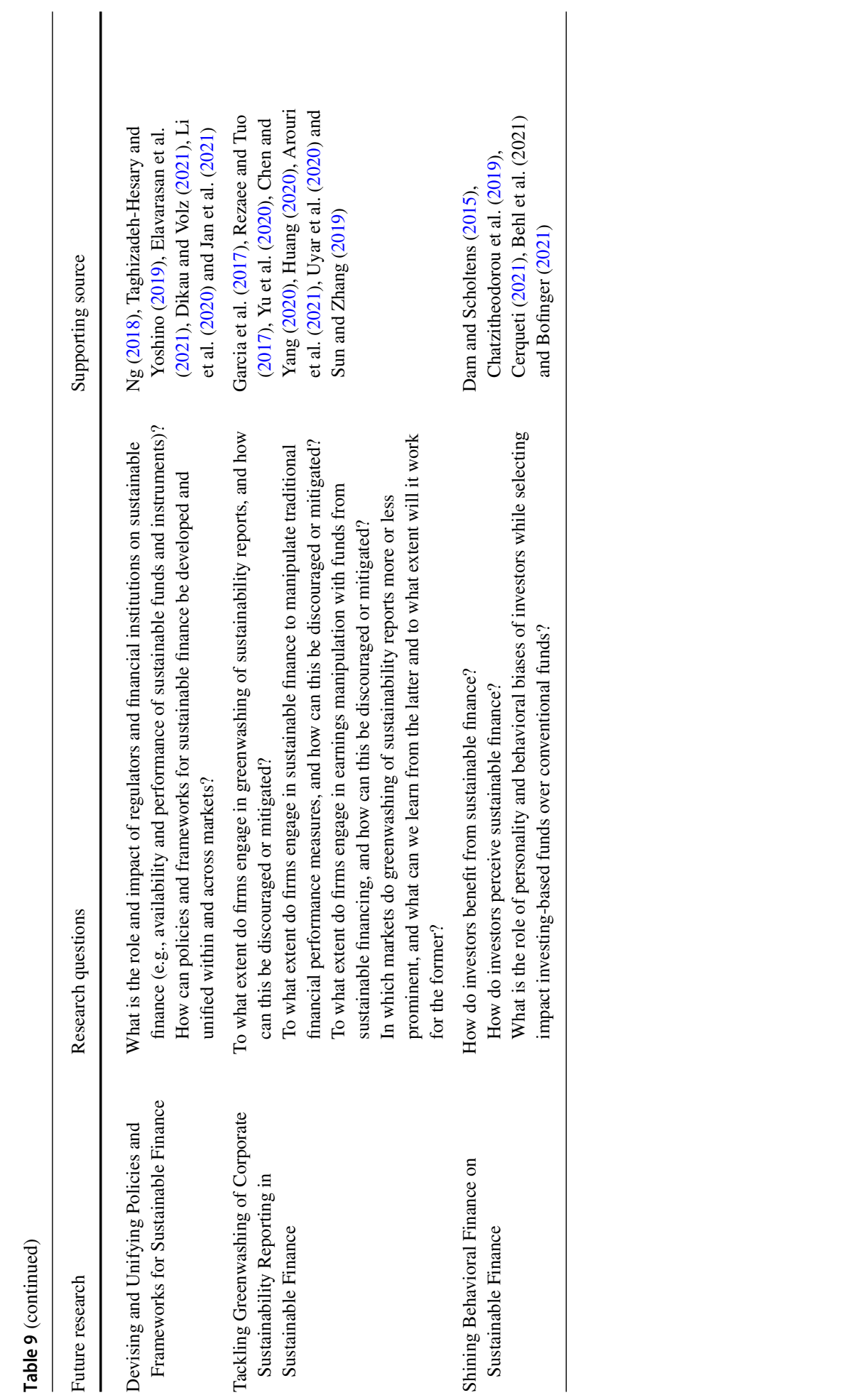




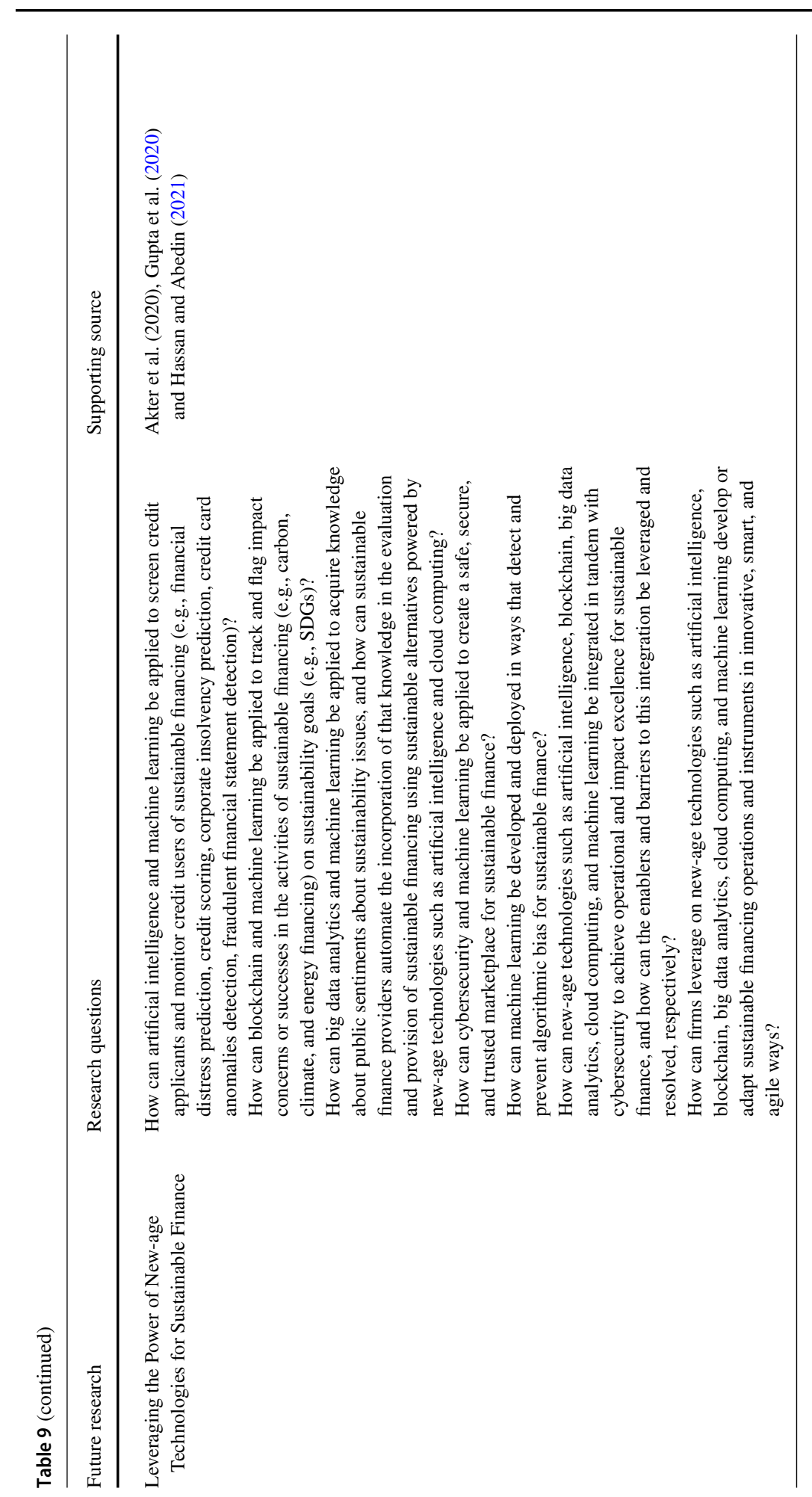


financing instruments, which can be applied to the existing ones discovered through our review or to propel the development of newer ones moving forward:

- What value do innovative sustainable financing instruments offer, and how can such value be improved or sustained?

- To what extent are innovative sustainable financing instruments feasible for adoption and implementation in emerging markets, and what actions can be taken to improve feasibility?

- To what extent are innovative sustainable financing instruments linked with investors preference, and what actions can be taken to improve that link?

- To what extent are innovative sustainable financing instruments successful in meeting their objectives, and what actions can be taken to improve or sustain success?

- How can formal and informal institutions curate, influence, and shape innovative sustainable financing instruments?

\subsection{Magnifying and managing the profitability and returns of sustainable financing}

The performance cost of sustainable financing can be managed through optimal adjustments of portfolios (Fu et al., 2020). However, the same may not be possible across all markets due to the limitations of available investment avenue sets and tied rewards with impact (Geczy et al., 2021). The intermediation cost is also higher for sustainable financing than traditional financing as on the one hand firms in low-income countries with social impact do not have access to funds (World Bank Enterprise Survey, 2017) while on the other hand many investors in high-income countries are unable to find the right cause to invest (Kollenda, 2021). Moreover, it was found that the finance cost of green bonds is no less than non-green bonds in China (Cao et al., 2021). Therefore, future research needs to offer new ways to manage the profitability and returns of sustainable financing in lucrative and sensible ways, as summarized through the following research questions:

- What are the benefits, costs, opportunities, and threats of sustainable financing across markets?

- How can the benefits, costs, opportunities, threats, and ways forward for sustainable financing be conceptualized in and managed through an operational framework that accounts for and speaks to myriad stakeholders (investors, institutions, regulators)?

\subsection{Making sustainable finance more sustainable}

Assessing the sustainability of sustainable finance and rewards of impact investing is difficult. Investors also often demand non-financial performance metrics for such investments, with carbon footprints, exposure metrics, and ESG ratings gaining popularity despite their inherent limitations and shortcomings (Popescu et al., 2021). Dorfleitner et al. (2021) found most of socially responsible funds in the United States to be marred by persistent ESG controversies, which have led to calls by scholars such as Quatrini (2021) for mechanisms and strategies to address the existing flaws in the assessment of sustainable investments, which is both important and urgent to accelerate the world's recovery from the aftermath of the devastating effects of the COVID-19 pandemic on the progress of sustainability (United Nations, 2021). Therefore, we encourage future research to pursue three research questions that should make sustainable finance more sustainable:

- To what extent does investing in sustainable funds lead to sustainable returns, and how can it be improved or sustained? 
- To what extent does sustainable finance enable firms to avoid controversy related to ESG, and how can it be improved or sustained?

- To what extent are sustainable funds sustainable before, during, and after crises such as the COVID-19 pandemic?

\subsection{Devising and unifying policies and frameworks for sustainable finance}

Regulators and financial institutions are pushing forth the sustainable finance agenda to attain the SDGs across markets (Dikau \& Volz, 2021; Elavarasan et al., 2021; Taghizadeh-Hesary $\&$ Yoshino, 2019). Past research has indicated that the integration of green financial systems in traditional financial system can lead to sustainability controls and cleaner production $(\mathrm{Ng}$, 2018), and that the incorporation of green governance structures can assist in lower financing constraints (Li et al., 2020), which suggest that regulators and financial institutions need to set up sustainability performance policies and frameworks (Jan et al., 2021). Yet, myriad policies and frameworks exist within and across markets, wherein such inconsistencies or non-complementariness can hinder the potential of sustainable finance. Hence, it is important to understand the role of regulators and financial institutions in sustainable finance, and crucial to that understanding is the development and unifying of policies and frameworks that communicates a common and mutual language, which are noteworthy directions for future research that we summarized through the following research questions:

- What is the role and impact of regulators and financial institutions on sustainable finance (e.g., availability and performance of sustainable funds and instruments)?

- How can policies and frameworks for sustainable finance be developed and unified within and across markets?

\subsection{Tackling greenwashing of corporate sustainability reporting in sustainable finance}

While earlier studies focused on the positive signals of ESG and impact investing on firm performance and concluded strong evidences of higher financial performance (Garcia et al., 2017; Rezaee \& Tuo, 2017), recent studies have started questioning the quality of corporate sustainability reporting metrices and provided strong evidences of greenwashing of sustainability reports across markets (Arouri et al., 2021; Chen \& Yang, 2020; Huang, 2020; Yu et al., 2020), with few studies rejecting greenwashing tendency of firms across sectors and markets (Uyar et al., 2020). Government regulations in the form of penalties and tax subsidies have nonetheless been evidenced to be effective to mitigate greenwashing in China (Sun \& Zhang, 2019). Nonetheless, the evidence that avail remains inconclusive and limited, thereby suggesting potential for future research, especially across markets. Therefore, we propose the following research questions for future undertaking:

- To what extent do firms engage in greenwashing of sustainability reports, and how can this be discouraged or mitigated?

- To what extent do firms engage in sustainable finance to manipulate traditional financial performance measures, and how can this be discouraged or mitigated?

- To what extent do firms engage in earnings manipulation with funds from sustainable financing, and how can this be discouraged or mitigated?

- In which markets do greenwashing of sustainability reports more or less prominent, and what can we learn from the latter and to what extent will it work for the former? 


\subsection{Shining behavioral finance on sustainable finance}

In the American and European stock markets, socially responsible investing is associated with large firms and abnormal returns (Mollet \& Ziegler, 2014), with many socially responsible investors willing to forgo financial performance to pursue ethical or social objectives (Renneboog et al., 2008). Most scholars focus on the comparative performance between socially responsible funds and traditional funds along with associated screening and evaluation criteria (Chatzitheodorou et al., 2019), with studies showing better performance of socially responsible funds over traditional funds (Pedersen et al., 2020), higher market-tobook ratios and higher return on assets for socially responsible investors (Dam \& Scholtens, 2015), and an opportunity to reduce systematic risk for investors (Cerqueti, 2021; Behl et al., 2021). However, little is known about the actual perceptions and behaviors toward sustainable finance, including that of and beyond socially responsible investing, which may be due to the lack of quantitative and survey social science-oriented research in sustainable finance. This is particular important given that the outperformance of sustainable finance may not necessarily continue in the long run due to the external shocks such as the COVID-19 pandemic, the increasing awareness of greenwashing of sustainability reports, and the overpricing such stocks (Bofinger, 2021). In this regard, we call for additional research that seeks to shine a behavioral finance light in this direction through the following research questions:

- How do investors benefit from sustainable finance?

- How do investors perceive sustainable finance?

- What is the role of personality and behavioral biases of investors while selecting impact investing-based funds over conventional funds?

\subsection{Leveraging the power of new-age technologies for sustainable finance}

Last by not least, in our final reflection of this review, we stumbled upon the greatly astonishing state of sustainable finance, wherein the application and discussion of new-age technologies in sustainable finance research is almost virtually non-existent despite its omnipresence in other fields such as business sustainability (Sivarajah et el., 2020), sustainable automotive (Kamble et al., 2021) and humanitarian supply chain (Bag et al., 2020), sustainable logistics service quality (Gupta et al., 2021), and sustainability marketing (Bolton, 2021). In essence, new-age technologies refer to new technologies that emerge as new industrial revolutions surface, with technologies such as artificial intelligence, blockchain, internet of things, and machine learning being born out of the recent fourth industrial revolution (IR4.0) (Gupta et al., 2020). Noteworthily, IR4.0 is characterized as an era of digital transformation, which holds great potential for sustainability (Roblek et al., 2020). In fact, new solutions to get the world's progress on sustainability back on track has never been greater given that the COVID19 pandemic has reversed years of existing progress (United Nations, 2021), and we opine that future research that explains how new-age technologies can be applied to sustainable finance can make significant contributions to the world's recovery and prosperity in the postpandemic era, a contention that is supported by the central role that finance plays in funding digital transformation (Akter et al., 2020) and sustainability endeavors Cunha et al. (2021). In this regard, we call for new research that deliberately ignites and proliferates insights on the application of new-age technologies for sustainable finance through the following research questions:

- How can artificial intelligence and machine learning be applied to screen credit applicants and monitor credit users of sustainable financing (e.g., financial distress prediction, 
credit scoring, corporate insolvency prediction, credit card anomalies detection, fraudulent financial statement detection)?

- How can blockchain and machine learning be applied to track and flag impact concerns or successes in the activities of sustainable financing (e.g., carbon, climate, and energy financing) on sustainability goals (e.g., SDGs)?

- How can big data analytics and machine learning be applied to acquire knowledge about public sentiments about sustainability issues, and how can sustainable finance providers automate the incorporation of that knowledge in the evaluation and provision of sustainable financing using sustainable alternatives powered by new-age technologies such as artificial intelligence and cloud computing?

- How can cybersecurity and machine learning be applied to create a safe, secure, and trusted marketplace for sustainable finance?

- How can machine learning be developed and deployed in ways that detect and prevent algorithmic bias for sustainable finance?

- How can new-age technologies such as artificial intelligence, blockchain, big data analytics, cloud computing, and machine learning be integrated in tandem with cybersecurity to achieve operational and impact excellence for sustainable finance, and how can the enablers and barriers to this integration be leveraged and resolved, respectively?

- How can firms leverage on new-age technologies such as artificial intelligence, blockchain, big data analytics, cloud computing, and machine learning develop or adapt sustainable financing operations and instruments in innovative, smart, and agile ways?

\section{Conclusion}

This study follows a systematic literature review approach using bibliometric analysis to shed light on the performance and science of sustainable finance research. This approach, which exemplifies the use of big data analytics through machine learning of scholarly research, is especially noteworthy given the astonishing absence of the application and discussion of new-age technologies in sustainable finance research. In doing so, this study contributes in a novel way by leveraging on the power of big data analytics through machine learning - and providing greater visibility to it in the process - to uncover the most influential articles and top contributing journals, authors, institutions, and countries, as well as the methodological choices and research contexts, and by revealing the temporal evolution of topics and the major themes underpinning the intellectual structure for sustainable finance research. To this end, we summarize five key takeaways and their equivalent implications from this state-of-the-art review of 936 articles on sustainable finance over the last 35 years (1986-2020).

First, the performance analysis indicates a consistent growth in publications in the field following the Paris agreement and the launch of the SDGs. Most publications came from authors and institutions in the United States and the United Kingdom as these countries have adopted sustainable finance frameworks and engaging in socially responsible investing much earlier than other developed and developing countries. In this regard, sustainable finance research should expand to underrepresented countries where sustainable finance is gaining momentum (e.g., Africa, Australia, Japan, Malaysia, and Singapore).

Second, the performance analysis also reveals that qualitative research is most prominent in sustainable finance due to the nascent stage of its adoption in most countries and thus the lack of cases and data points required for quantitative research, and that most researchers preferred archival data, with few opting to pursue experiments and surveys. In this regard, it 
may be worthwhile for sustainable finance research to pursue the latter two data collection techniques that remain underutilized due to their potential to measure chronic and primed responses (Lim, 2015, 2021; Lim et al., 2019) among potential stakeholders of sustainable finance, thereby curating equally interesting cause-and-effect insights on its feasibility and market reaction prior to its start up or scale up.

Third, the performance analysis also shows that most studies are application oriented where the aim is to develop policies and frameworks for specific contexts rather than to build and test theories, that most studies focus on single country data where earlier studies concentrate on developed economies such as Europe, the United States, and the United Kingdom and more recent studies coming from emerging economies such as Asia, Africa, and Oceania, and that most studies are inclined toward the service sector, specifically financial services. Therefore, we encourage prospective researchers to proactively view these gaps as opportunities for making new and novel contributions to the enrich and extend understanding of sustainable finance.

Fourth, the science mapping through a temporal analysis reveals that sustainable finance research has contributed myriad insights overtime starting with a single focus on socially responsible investing (1986 onwards) and branching out progressively to other areas such as ethical and green financing and ethical investing (1995 onwards), carbon financing, climate financing, conscious capitalism, CSR, and ESG (2005 onwards), and more recently, impact investing, innovative financial instrument, and SDG (2015 onwards). Noteworthily, the field of sustainable finance will only grow larger in the future, with new innovative sustainable financing instruments being developed over time - as seen through the rise of carbon and climate financing - to shape and satisfy the demands of funding for sustainability and sustainability development.

Fifth, the science mapping through a network analysis of keyword co-occurrence unveils seven major themes that characterize the body of knowledge or the intellectual structure of sustainable finance research, namely socially responsible investing, climate financing, green financing, impact investing, carbon financing, energy financing, and governance of sustainable financing and investing. We observe that six out of seven major themes relate to the types of sustainable finance, with governance being a unique theme on its own. Noteworthily, our reading of the articles and reflection of the extant gaps under each major theme brought us to several underexplored or underrepresented issues that future research can take up to enrich the major themes in sustainable finance research, which include developing and diffusing innovative sustainable financing instruments, magnifying and managing the profitability and returns of sustainable financing, making sustainable finance more sustainable, devising and unifying policies and frameworks for sustainable finance, tackling greenwashing of corporate sustainability reporting in sustainable finance, shining behavioral finance on sustainable finance, and leveraging the power of new-age technologies for sustainable finance.

Notwithstanding the extant contributions from this seminal state-of-the-art review of sustainable finance research, we concede that our review remains limited in several ways. First, our review is limited to the accuracy and completeness of articles made available through the Scopus database. Nonetheless, we have taken due diligence to correct for errorneous entries and to cross-check against publisher websites and other databases to mitigate this limitation. Second, our review provides only a broad overview of the performance and intellectual structure of sustainable finance research. Though this is in line with the goal and value of systematic literature reviews using a bibliometric analysis, wherein large-scale reviews become pragmatically possible, we concede that this approach falls short of providing finer-grained insights into other deserving and interesting pecularties such as the factors (independent, mediating, moderating, dependent) and relationships (positive, negative, linear, curvilinear) 
that may entail in sustainable finance. In this regard, we encourage future reviews using alternative approaches such as a framework- or theory-based review on sustainable finance, though such reviews do not necessarily need to be large scale-they can be pursued on a smaller scale (e.g., tens to low hundreds of articles) so that the review remains pragmatic and managable, as in the case of Cunha et al. (2021).

\section{References}

Abadie, L. M., Galarraga, I., \& Rübbelke, D. (2013). An analysis of the causes of the mitigation bias in international climate finance. Mitigation and Adaptation Strategies for Global Change, 18(7), 943-955.

Aglietta, M., Hourcade, J. C., Jaeger, C., \& Fabert, B. P. (2015). Financing transition in an adverse context: Climate finance beyond carbon finance. International Environmental Agreements: Politics, Law and Economics, 15(4), 403-420.

Agrawal, A., \& Hockerts, K. (2019). Impact investing strategy: Managing conflicts between impact investor and investee social enterprise. Sustainability, 11(15), 4117.

Agrawal, A., \& Hockerts, K. (2021). Impact investing: Review and research agenda. Journal of Small Business \& Entrepreneurship, 33(2), 153-181.

Alda, M. (2020). ESG fund scores in UK SRI and conventional pension funds: Are the ESG concerns of the SRI niche affecting the conventional mainstream? Finance Research Letters, 36, 101313.

Alda, M. (2021). The environmental, social, and governance (ESG) dimension of firms in which social responsible investment (SRI) and conventional pension funds invest: The mainstream SRI and the ESG inclusion. Journal of Cleaner Production, 298, 126812.

Alessandrini, F., \& Jondeau, E. (2020). ESG investing: From sin stocks to smart beta. The Journal of Portfolio Management, 46(3), 75-94.

Alsaifi, K., Elnahass, M., \& Salama, A. (2020). Carbon disclosure and financial performance: UK environmental policy. Business Strategy and the Environment, 29(2), 711-726.

Ari, I., \& Koc, M. (2021). Philanthropic-crowdfunding-partnership: A proof-of-concept study for sustainable financing in low-carbon energy transitions. Energy, 222, 119925.

Arouri, M., El Ghoul, S., \& Gomes, M. (2021). Greenwashing and product market competition. Finance Research Letters, 42, 101927. (in press).

Baker, H. K., Pandey, N., Kumar, S., \& Haldar, A. (2020). A bibliometric analysis of board diversity: Current status, development, and future research directions. Journal of Business Research, 108, 232-246.

Bag, S., Gupta, S., \& Wood, L. (2020). Big data analytics in sustainable humanitarian supply chain: Barriers and their interactions. Annals of Operations Research. https://doi.org/10.1007/s10479-020-03790-7

Barua, S., \& Chiesa, M. (2019). Sustainable financing practices through green bonds: What affects the funding size? Business Strategy and the Environment, 28(6), 1131-1147.

Bauer, R., Derwall, J., \& Otten, R. (2007). The ethical mutual fund performance debate: New evidence from Canada. Journal of Business Ethics, 70(2), 111-124.

Belghitar, Y., Clark, E., \& Deshmukh, N. (2014). Does it pay to be ethical? Evidence from the FTSE4Good. Journal of Banking \& Finance, 47, 54-62.

Bofinger, Y., Heyden, K. J., Rock, B., \& Bannier, C. (2021). The sustainability trap: Active fund managers between ESG investing and fund overpricing. Finance Research Letters, 102160.

Bolton, R. N. (2021). The convergence of sustainability and marketing: Transforming marketing to respond to a new world. Australasian Marketing Journal. https://doi.org/10.1177/18393349211005200

Bredin, D., Hyde, S., \& Muckley, C. (2014). A microstructure analysis of the carbon finance market. International Review of Financial Analysis, 34, 222-234.

Broadus, R. N. (1987). Toward a definition of "bibliometrics." Scientometrics, 12(5-6), 373-379.

Brunner, S., \& Enting, K. (2014). Climate finance: A transaction cost perspective on the structure of state-tostate transfers. Global Environmental Change, 27, 138-143.

Bui, T. D., Ali, M. H., Tsai, F. M., Iranmanesh, M., Tseng, M. L., \& Lim, M. K. (2020). Challenges and trends in sustainable corporate finance: A bibliometric systematic review. Journal of Risk and Financial Management, 13(11), 264.

Burton, B., Kumar, S., \& Pandey, N. (2020). Twenty-five years of The European Journal of Finance (EJF): A retrospective analysis. The European Journal of Finance, 26(18), 1817-1841.

Callon, M., Courtial, J.-P., Turner, W. A., \& Bauin, S. (1983). From transaction to problematic networks: An introduction to co-word analysis. Social Science Information, 22(2), 191-235.

Camey, B. F. (1994). Socially responsible investing. Health Progress, 75, 20-23. 
Camilleri, M. A. (2020). The market for socially responsible investing: A review of the developments. Social Responsibility Journal, 17(3), 412-428.

Cao, X., Jin, C., \& Ma, W. (2021). Motivation of Chinese commercial banks to issue green bonds: Financing costs or regulatory arbitrage? China Economic Review, 66, 101582.

Carè, R., Rania, F., \& De Lisa, R. (2020). Critical success factors, motivations, and risks in social impact bonds. Sustainability, 12(18), 7291.

Caseau, C., \& Grolleau, G. (2020). Impact investing: Killing two birds with one stone? Financial Analysts Journal, 76(4), 40-52.

Castriotta, M., Loi, M., Marku, E., \& Naitana, L. (2019). What's in a name? Exploring the conceptual structure of emerging organizations. Scientometrics, 118(2), 407-437.

Cerqueti, R., Ciciretti, R., Dalò, A., \& Nicolosi, M. (2021). ESG investing: A chance to reduce systemic risk. Journal of Financial Stability, 54, 2021100887.

Chatzitheodorou, K., Skouloudis, A., Evangelinos, K., \& Nikolaou, I. (2019). Exploring socially responsible investment perspectives: A literature mapping and an investor classification. Sustainable Production and Consumption, 19, 117-129.

Chen, H. Y., \& Yang, S. S. (2020). Do investors exaggerate corporate ESG information? Evidence of the ESG momentum effect in the Taiwanese market. Pacific-Basin Finance Journal, 63, 101407.

Chen, L., Zhang, L., Huang, J., Xiao, H., \& Zhou, Z. (2021). Social responsibility portfolio optimization incorporating ESG criteria. Journal of Management Science and Engineering, 6(1), 75-85.

Chen, M., \& Mussalli, G. (2020). An integrated approach to quantitative ESG investing. The Journal of Portfolio Management, 46(3), 65-74.

Chen, Y., \& Ma, Y. (2021). Does green investment improve energy firm performance? Energy Policy, 153, 112252.

Cheng, C., Hua, Y., \& Tan, D. (2019). Spatial dynamics and determinants of sustainable finance: Evidence from venture capital investment in China. Journal of Cleaner Production, 232, 1148-1157.

Chow, G. W., Durand, R. B., \& Koh, S. (2014). Are ethical investments good? Australian Journal of Management, 39(4), 645-665.

Clark, R., Reed, J., \& Sunderland, T. (2018). Bridging funding gaps for climate and sustainable development: Pitfalls, progress and potential of private finance. Land Use Policy, 71, 335-346.

Clarkin, J. E., \& Cangioni, C. L. (2016). Impact investing: A primer and review of the literature. Entrepreneurship Research Journal, 6(2), 135-173.

Cobo, M. J., López-Herrera, A. G., Herrera-Viedma, E., \& Herrera, F. (2011). Science mapping software tools: Review, analysis, and cooperative study among tools. Journal of the American Society for Information Science and Technology, 62(7), 1382-1402.

Comerio, N., \& Strozzi, F. (2019). Tourism and its economic impact: A literature review using bibliometric tools. Tourism Economics, 25(1), 109-131.

Craig, C. D. (2021). Sustainable finance starts with data. World Economic Forum. Available at https://www. weforum.org/agenda/2020/01/sustainable-finance-starts-with-data/

Cui, H., Wang, R., \& Wang, H. (2020). An evolutionary analysis of green finance sustainability based on multi-agent game. Journal of Cleaner Production, 269, 121799.

Cunha, F. A. F. D. S., Meira, E., \& Orsato, R. J. (2021). Sustainable finance and investment: Review and research agenda. Business Strategy and the Environment. https://doi.org/10.1002/bse.2842

Dam, L., \& Scholtens, B. (2015). Toward a theory of responsible investing: On the economic foundations of corporate social responsibility. Resource and Energy Economics, 41, 103-121.

Daugaard, D. (2020). Emerging new themes in environmental, social and governance investing: A systematic literature review. Accounting \& Finance, 60(2), 1501-1530.

Dedusenko, E. A. (2017). Impact investing trends in Russia and tourism. Journal of Environmental Management and Tourism (JEMT), 8(08 (24)), 1474-1481.

Dikau, S., \& Volz, U. (2021). Central bank mandates, sustainability objectives and the promotion of green finance. Ecological Economics, 184, 107022.

Diltz, J. D. (1995). The private cost of socially responsible investing. Applied Financial Economics, 5(2), 69-77.

Donthu, N., Kumar, S., \& Pattnaik, D. (2020). Forty-five years of Journal of Business Research: A bibliometric analysis. Journal of Business Research, 109, 1-14.

Donthu, N., Kumar, S., Mukherjee, D., Pandey, N., \& Lim, W. M. (2021a). How to conduct a bibliometric analysis: An overview and guidelines. Journal of Business Research, 133, 285-296.

Donthu, N., Kumar, S., Pandey, N., \& Gupta, P. (2021b). Forty years of the International Journal of Information Management: A bibliometric analysis. International Journal of Information Management, 57, 102307. 
Donthu, N., Kumar, S., Pandey, N., \& Lim, W. M. (2021c). Research constituents, intellectual structure, and collaboration patterns in Journal of International Marketing: An analytical retrospective. Journal of International Marketing, 29(2), 1-25.

Donthu, N., Kumar, S., Pattnaik, D., \& Lim, W. M. (2021d). A bibliometric retrospection of marketing from the lens of psychology: Insights from Psychology \& Marketing. Psychology \& Marketing, 38(5), 834-865.

Dorfleitner, G., Halbritter, G., \& Nguyen, M. (2015). Measuring the level and risk of corporate responsibility-An empirical comparison of different ESG rating approaches. Journal of Asset Management, 16(7), $450-466$.

Dorfleitner, G., Kreuzer, C., \& Laschinger, R. (2021). How socially irresponsible are socially responsible mutual funds? A persistence analysis. Finance Research Letters, 43, 101990.

Durisin, B., \& Puzone, F. (2009). Maturation of corporate governance research, 1993-2007: An assessment. Corporate Governance: An International Review, 17(3), 266-291.

Eccles, N. S., \& Viviers, S. (2011). The origins and meanings of names describing investment practices that integrate a consideration of ESG issues in the academic literature. Journal of Business Ethics, 104(3), 389-402.

Elavarasan, R. M., Pugazhendhi, R., Shafiullah, G. M., Irfan, M., \& Anvari-Moghaddam, A. (2021). A hover view over effectual approaches on pandemic management for sustainable cities-The endowment of prospective technologies with revitalization strategies. Sustainable Cities and Society, 68, 102789.

Ellegaard, O., \& Wallin, J. A. (2015). The bibliometric analysis of scholarly production: How great is the impact? Scientometrics, 105(3), 1809-1831.

Escrig-Olmedo, E., Muñoz-Torres, M. J., \& Fernández-Izquierdo, M. Á. (2013). Sustainable development and the financial system: Society's perceptions about socially responsible investing. Business Strategy and the Environment, 22(6), 410-428.

European Commission. (2021). Overview of sustainable finance. European Commission. Available at https://ec.europa.eu/info/business-economy-euro/banking-and-finance/sustainable-finance/overviewsustainable-finance_en

Fabregat-Aibar, L., Barberà-Mariné, M. G., Terceño, A., \& Pié, L. (2019). A bibliometric and visualization analysis of socially responsible funds. Sustainability, 11(9), 2526.

Ferris, S. P., \& Rykaczewski, K. P. (1986). Social investing and portfolio management. Business \& Society, 25(1), 1-7.

Fonta, W. M., Ayuk, E. T., \& van Huysen, T. (2018). Africa and the Green Climate Fund: Current challenges and future opportunities. Climate Policy, 18(9), 1210-1225.

Friede, G., Busch, T., \& Bassen, A. (2015). ESG and financial performance: Aggregated evidence from more than 2000 empirical studies. Journal of Sustainable Finance \& Investment, 5(4), 210-233.

Fu, Y., Wright, D., \& Blazenko, G. (2020). Ethical investing has no portfolio performance cost. Research in International Business and Finance, 52, 101117.

Garcia, A. S., Mendes-Da-Silva, W., \& Orsato, R. J. (2017). Sensitive industries produce better ESG performance: Evidence from emerging markets. Journal of Cleaner Production, 150, 135-147.

Geczy, C., Jeffers, J. S., Musto, D. K., \& Tucker, A. M. (2021). Contracts with (social) benefits: The implementation of impact investing. Journal of Financial Economics. https://doi.org/10.1016/j.jfineco.2021. 01.006

Geobey, S. E. A. N., \& Callahan, J. E. N. N. I. F. E. R. (2017). Managing impact portfolios: A conceptual view of scale. ACRN Oxford Journal of Finance and Risk Perspectives, 6(4), 17-36.

Giacomantonio, C. (2017). Grant-maximizing but not money-making: A simple decision-tree analysis for social impact bonds. Journal of Social Entrepreneurship, 8(1), 47-66.

Giese, G., Lee, L. E., Melas, D., Nagy, Z., \& Nishikawa, L. (2019). Foundations of ESG investing: How ESG affects equity valuation, risk, and performance. Journal of Portfolio Management, 45(5), 69-83.

Giglio, S., Kelly, B. T., \& Stroebel, J. (2020). Climate finance. NBER Working Paper (w28226).

Goyal, K., Kumar, S., \& Xiao, J. J. (2021). Antecedents and consequences of personal financial management behavior: A systematic literature review and future research agenda. International Journal of Bank Marketing. https://doi.org/10.1108/IJBM-12-2020-0612

Guerard, J. B., Jr. (1997). Is there a cost to being socially responsible in investing? Journal of Forecasting, 16(7), 475-490.

Gupta, A., Singh, R. K., \& Mangla, S. K. (2021). Evaluation of logistics providers for sustainable service quality: Analytics based decision making framework. Annals of Operations Research. https://doi.org/10. 1007/s10479-020-03913-0

Gupta, S., Kumar, V., \& Karam, E. (2020). New-age technologies-driven social innovation: What, how, where, and why? Industrial Marketing Management, 89, 499-516. 
Gupta, S., Verma, R., \& Victorino, L. (2009). Empirical research published in Production and Operations Management (1992-2005): Trends and future research directions. Production and Operations Management, $15(3), 432-448$.

Gutiérrez, M., \& Gutiérrez, G. (2019). Climate finance: Perspectives on climate finance from the bottom up. Development, 62(1), 136-146.

Halbritter, G., \& Dorfleitner, G. (2015). The wages of social responsibility-Where are they? A critical review of ESG investing. Review of Financial Economics, 26, 25-35.

Harari, M. B., Parola, H. R., Hartwell, C. J., \& Riegelman, A. (2020). Literature searches in systematic reviews and meta-analyses: A review, evaluation, and recommendations. Journal of Vocational Behavior, 118, 103377.

Harmeling, S., \& Kaloga, A. O. (2011). Understanding the political economy of the adaptation fund. IDS Bulletin, 42(3), 23-32.

Hassan, M. K., \& Abedin, M. Z. (2021). Special issue: Machine learning technologies on energy economics and finance in times of crisis. Annals of Operations Research. https://resource-cms.springernature.com/ springer-cms/rest/v1/content/18979044/data/v1

Heinkel, R., Kraus, A., \& Zechner, J. (2001). The effect of green investment on corporate behavior. Journal of Financial and Quantitative Analysis, 36(4), 431-449.

Herremans, I. M., Akathaporn, P., \& McInnes, M. (1993). An investigation of corporate social responsibility reputation and economic performance. Accounting, Organizations and Society, 18(7-8), 587-604.

Himick, D. (2011). Relative performance evaluation and pension investment management: A challenge for ESG investing. Critical Perspectives on Accounting, 22(2), 158-171.

Hogarth, J. R. (2012). The role of climate finance in innovation systems. Journal of Sustainable Finance \& Investment, 2(3-4), 257-274.

Huang, H., Xing, X., He, Y., \& Gu, X. (2020). Combating greenwashers in emerging markets: A gametheoretical exploration of firms, customers and government regulations. Transportation Research Part e: Logistics and Transportation Review, 140, 101976.

Hutton, R. B., D’Antonio, L., \& Johnsen, T. (1998). Socially responsible investing: Growing issues and new opportunities. Business \& Society, 37(3), 281-305.

Ibrahim, K., Shabudin, A. F. A., Chacko Koshy, K., \& Asrar, G. R. (2016). A new framework for integrated climate finance and inclusive responses to sustainable development in Malaysia. Geomatics, Natural Hazards and Risk, 7(6), 1754-1768.

Jackson, E. T. (2013a). Evaluating social impact bonds: Questions, challenges, innovations, and possibilities in measuring outcomes in impact investing. Community Development, 44(5), 608-616.

Jackson, E. T. (2013b). Interrogating the theory of change: Evaluating impact investing where it matters most. Journal of Sustainable Finance \& Investment, 3(2), 95-110.

Jafri, J. (2019). When billions meet trillions: Impact investing and shadow banking in Pakistan. Review of International Political Economy, 26(3), 520-544.

Jakob, M., Steckel, J. C., Flachsland, C., \& Baumstark, L. (2015). Climate finance for developing country mitigation: Blessing or curse? Climate and Development, 7(1), 1-15.

Jan, A. A., Lai, F. W., \& Tahir, M. (2021). Developing an Islamic Corporate Governance framework to examine sustainability performance in Islamic Banks and Financial Institutions. Journal of Cleaner Production, $315,128099$.

Joliet, R., \& Titova, Y. (2018). Equity SRI funds vacillate between ethics and money: An analysis of the funds' stock holding decisions. Journal of Banking \& Finance, 97, 70-86.

Kamble, S. S., Gunasekaran, A., Subramanian, N., Ghadge, A., Belhadi, A., \& Venkatesh, M. (2021). Blockchain technology's impact on supply chain integration and sustainable supply chain performance: Evidence from the automotive industry. Annals of Operations Research. https://doi.org/10.1007/s10479021-04129-6

Khan, M. A., Pattnaik, D., Ashraf, R., Ali, I., Kumar, S., \& Donthu, N. (2021). Value of special issues in the Journal of Business Research: A bibliometric analysis. Journal of Business Research, 125, 295-313.

Kling, G., Volz, U., Murinde, V., \& Ayas, S. (2021). The impact of climate vulnerability on firms' cost of capital and access to finance. World Development, 137, 105131.

Kollenda, P. (2021). Financial returns or social impact? What motivates impact investors' lending to firms in low-income countries. Journal of Banking \& Finance, 106224.

Kumar, S., Lim, W. M., Pandey, N., \& Westland, J. C. (2021a). 20 years of Electronic Commerce Research. Electronic Commerce Research, 21(1), 1-40.

Kumar, S., Pandey, N., Lim, W. M., Chatterjee, A. N., \& Pandey, N. (2021b). What do we know about transfer pricing? Insights from bibliometric analysis. Journal of Business Research, 134, 275-287. 
Kumar, S., Sureka, R., Lim, W. M., Mangla, S. M., \& Goyal, N. (2021c). What do we know about business strategy and environmental research? Insights from business strategy and the environment. Business Strategy and the Environment. https://doi.org/10.1002/bse.2813

La Torre, M., Trotta, A., Chiappini, H., \& Rizzello, A. (2019). Business models for sustainable finance: The case study of social impact bonds. Sustainability, 11(7), 1887.

Landi, G., \& Sciarelli, M. (2019). Towards a more ethical market: The impact of ESG rating on corporate financial performance. Social Responsibility Journal, 15(1), 11-27.

Lesser, K., Lobe, S., \& Walkshäusl, C. (2014). Green and socially responsible investing in international markets. Journal of Asset Management, 15(5), 317-331.

Li, W., Zheng, M., Zhang, Y., \& Cui, G. (2020). Green governance structure, ownership characteristics, and corporate financing constraints. Journal of Cleaner Production, 260, 121008.

Lieberman, D. (2020). Impact investing 2.0-Not just for do-gooders anymore. The Journal of Investing, 29(2), 58-69.

Lim, W. M. (2015). Enriching information science research through chronic disposition and situational priming: A short note for future research. Journal of Information Science, 41(3), 399-402.

Lim, W. M. (2021). Conditional recipes for predicting impacts and prescribing solutions for externalities: The case of COVID-19 and tourism. Tourism Recreation Research, 46(2), 314-318.

Lim, W. M., Ahmed, P. K., \& Ali, M. Y. (2019). Data and resource maximization in business-to-business marketing experiments: Methodological insights from data partitioning. Industrial Marketing Management, 76, 136-143.

Lim, W. M., Yap, S. F., \& Makkar, M. (2021). Home sharing in marketing and tourism at a tipping point: What do we know, how do we know, and where should we be heading? Journal of Business Research, 122, 534-566.

Lokuwaduge, C. S. D. S., \& Heenetigala, K. (2017). Integrating environmental, social and governance (ESG) disclosure for a sustainable development: An Australian study. Business Strategy and the Environment, 26(4), 438-450.

MacDonald, A., Clarke, A., \& Huang, L. (2019). Multi-stakeholder partnerships for sustainability: Designing decision-making processes for partnership capacity. Journal of Business Ethics, 160(2), 409-426.

Marti, E. (2013). Investing for a property-owning democracy? Towards a philosophical analysis of investment practices. Analyse \& Kritik, 35(1), 219-236.

Mekonnen, A. (2014). Economic costs of climate change and climate finance with a focus on Africa. Journal of African Economies, 23(suppl_2), ii50-ii82.

Malhotra, G., \& Thakur, K. S. (2020). Evolution of green finance: A bibliometric approach. Gedrag \& Organisatie Review, 33(2), 583-594.

Migliorelli, M. (2021). What do we mean by sustainable finance? Assessing existing frameworks and policy risks. Sustainability, 13(2), 975.

Mollet, J. C., \& Ziegler, A. (2014). Socially responsible investing and stock performance: New empirical evidence for the US and European stock markets. Review of Financial Economics, 23(4), 208-216.

Muganyi, T., Linnan, Y., \& Sun, H. P. (2021). Green Finance, Fintech and environmental protection: Evidence from China. Environmental Science and Ecotechnology, 7, 100107.

Muhamat, A. A., Jaafar, M. N., Basri, M. F., Alwi, S. F. S., \& Mainal, S. A. (2017). Green takaful as a climate finance tool. Advanced Science Letters, 23(8), 7670-7673.

Newman, M. E. J., \& Girvan, M. (2004). Finding and evaluating community structure in networks. Physical Review E, 69(2), 026113.

$\mathrm{Ng}$, A. W. (2018). From sustainability accounting to a green financing system: Institutional legitimacy and market heterogeneity in a global financial centre. Journal of Cleaner Production, 195, 585-592.

Nielsen, K. P., \& Noergaard, R. W. (2011). CSR and mainstream investing: A new match? An analysis of the existing ESG integration methods in theory and practice and the way forward. Journal of Sustainable Finance \& Investment, 1(3-4), 209-221.

Norris, M., \& Oppenheim, C. (2007). Comparing alternatives to the Web of Science for coverage of the social sciences' literature. Journal of Informetrics, 1(2), 161-169.

OECD. (2020). Developing sustainable finance definitions and taxonomies. Green Finance and Investment, OECD Publishing.

Paul, J., Lim, W. M., O'Cass, A., Hao, A. W., \& Bresciani, S. (2021). Scientific procedures and rationales for systematic literature reviews (SPAR-4-SLR). International Journal of Consumer Studies, 45(4), O1-O16.

Pattnaik, D., Hassan, M. K., Kumar, S., \& Paul, J. (2020). Trade credit research before and after the global financial crisis of 2008-A bibliometric overview. Research in International Business and Finance, 54, 101287.

Pedersen, L. H., Fitzgibbons, S., \& Pomorski, L. (2020). Responsible investing: The ESG-efficient frontier. Journal of Financial Economics. https://doi.org/10.1016/j.jfineco.2020.11.001 
Pender, H., \& Brocchetto, M. (2011). Retail investors and ethical investment. JASSA, 3, 26-31.

Pesta, B., Fuerst, J., \& Kirkegaard, E. (2018). Bibliometric keyword analysis across seventeen years (2000-2016) of intelligence articles. Journal of Intelligence, 6(4), 46.

Pierce, T. J. (1993). Keynes' personal investing: Activities and beliefs. The Social Science Journal, 30(1), 13-22.

Pinsky, V. C., Kruglianskas, I., Gomes, C. M., \& Rezaee, A. (2019). Sustainability research: A grounded theory approach in the field of climate change. Revista de Gestão Ambiental e Sustentabilidade, 8(3), 468-488.

Pinsky, V., Kruglianskas, I., \& Gomes, C. M. (2020). Conducting research in climate finance in Latin America: Challenges and opportunities of using grounded theory methodology approach. Global Journal of Flexible Systems Management, 21, 49-60.

Popescu, I. S., Hitaj, C., \& Benetto, E. (2021). Measuring the sustainability of investment funds: A critical review of methods and frameworks in sustainable finance. Journal of Cleaner Production, 314, 128016.

Purdon, M. (2015). Opening the black box of carbon finance "additionality": The political economy of carbon finance effectiveness across Tanzania, Uganda, and Moldova. World Development, 74, 462-478.

Quatrini, S. (2021). Challenges and opportunities to scale up sustainable finance after the COVID-19 crisis: Lessons and promising innovations from science and practice. Ecosystem Services, 48, 101240.

Rahman, M., Isa, C. R., Tu, T. T., Sarker, M., \& Masud, M. A. K. (2020). A bibliometric analysis of socially responsible investment sukuk literature. Asian Journal of Sustainability and Social Responsibility, 5 , $1-19$.

Rajan, A. T., Koserwal, P., \& Keerthana, S. (2014). The Global epicenter of impact investing: An analysis of social venture investments in India. The Journal of Private Equity, 17(2), 37-50.

Rao, P., Kumar, S., Chavan, M., \& Lim, W. M. (2021). A systematic literature review on SME financing: Trends and future directions. Journal of Small Business Management. https://doi.org/10.1080/00472778.2021. 1955123

Refinitiv. (2020). Sustainable finance review. Refinitiv. Available at https://www.refinitiv.com/content/dam/ marketing/en_us/documents/reports/sustainable-finance-review-first-nine-months-2020-hsbc.pdf

Renneboog, L., Ter Horst, J., \& Zhang, C. (2008). Socially responsible investments: Institutional aspects, performance, and investor behavior. Journal of Banking \& Finance, 32(9), 1723-1742.

Revelli, C., \& Viviani, J. L. (2015). Financial performance of socially responsible investing (SRI): What have we learned? A meta-analysis. Business Ethics: A European Review, 24(2), 158-185.

Rezaee, Z., \& Tuo, L. (2017). Voluntary disclosure of non-financial information and its association with sustainability performance. Advances in Accounting, 39, 47-59.

Richardson, B. J. (2009). Keeping ethical investment ethical: Regulatory issues for investing for sustainability. Journal of Business Ethics, 87(4), 555-572.

Richardson, B. J. (2014). The evolving marketscape of climate finance. Climate Law, 4(1-2), 94-106.

Rizzello, A., \& Kabli, A. (2020). Sustainable financial partnerships for the SDGs: The case of social impact bonds. Sustainability, 12(13), 5362.

Robb, R., \& Sattell, M. (2016). Socially responsible/impact investing: Theoretical and empirical issues. Capitalism and Society, 11(2), 2.

Roblek, V., Thorpe, O., Bach, M. P., Jerman, A., \& Meško, M. (2020). The fourth industrial revolution and the sustainability practices: A comparative automated content analysis approach of theory and practice. Sustainability, 12(20), 8497.

Roehrer, C., \& Kouadio, K. E. (2015). Monitoring, reporting, and evidence-based learning in the climate investment funds' pilot program for climate resilience. New Directions for Evaluation, 2015(147), 129-145.

Roundy, P. T. (2019). Regional differences in impact investment: A theory of impact investing ecosystems. Social Responsibility Journal, 16(4), 467-485.

Säve-Söderbergh, J. (2010). Who lets ethics guide his economic decision-making? An empirical analysis of individual investments in ethical funds. Economics Letters, 107(2), 270-272.

Schramade, W. (2016). Integrating ESG into valuation models and investment decisions: The value-driver adjustment approach. Journal of Sustainable Finance \& Investment, 6(2), 95-111.

Schulz, K. A., Gstrein, O. J., \& Zwitter, A. J. (2020). Exploring the governance and implementation of sustainable development initiatives through blockchain technology. Futures, 122, 102611.

Sinha, A., Mishra, S., Sharif, A., \& Yarovaya, L. (2021). Does green financing help to improve environmental \& social responsibility? Designing SDG framework through advanced quantile modelling. Journal of Environmental Management, 292, 112751.

Sisodia, G. S., Awad, E., Alkhoja, H., \& Sergi, B. S. (2020). Strategic business risk evaluation for sustainable energy investment and stakeholder engagement: A proposal for energy policy development in the Middle East through Khalifa funding and land subsidies. Business Strategy and the Environment, 29(6), 2789-2802. 
Sisodia, R. S. (2009). Doing business in the age of conscious capitalism. Journal of Indian Business Research, $1(2 / 3), 188-192$.

Sisodia, R. S. (2013). Understanding the performance drivers of conscious firms. California Management Review, 55(3), 87-96.

Sivarajah, U., Irani, Z., Gupta, S., \& Mahroof, K. (2020). Role of big data and social media analytics for business to business sustainability: A participatory web context. Industrial Marketing Management, 86, 163-179.

Skovgaard, J. (2015). Greener than expected? EU finance ministries address climate finance. Environmental Politics, 24(6), 951-969.

Statman, M. (2000). Socially responsible mutual funds. Financial Analysts Journal, 56(3), 30-39.

Sun, Z., \& Zhang, W. (2019). Do government regulations prevent greenwashing? An evolutionary game analysis of heterogeneous enterprises. Journal of Cleaner Production, 231, 1489-1502.

Taghizadeh-Hesary, F., \& Yoshino, N. (2019). The way to induce private participation in green finance and investment. Finance Research Letters, 31, 98-103.

Tan, L. H., Chew, B. C., \& Hamid, S. R. (2017). Service quality implementation in shaping sustainable banking operating system: A case study of Maybank Group. Qualitative Research in Financial Markets, 9(4), 359-381.

Tang, D. Y., \& Zhang, Y. (2020). Do shareholders benefit from green bonds? Journal of Corporate Finance, $61,101427$.

Thomä, J., Hayne, M., Hagedorn, N., Murray, C., \& Grattage, R. (2019). The alignment of global equity and corporate bonds markets with the Paris Agreement: A new accounting framework. Journal of Applied Accounting Research, 20(4), 439-457.

Tian, P., \& Lin, B. (2019). Impact of financing constraints on firm's environmental performance: Evidence from China with survey data. Journal of Cleaner Production, 217, 432-439.

United Nations. (2020). The sustainable development agenda. Available at https://www.un.org/ sustainabledevelopment/development-agenda/.

United Nations. (2021). UN report finds COVID-19 is reversing decades of progress on poverty, healthcare and education. Available at https://www.un.org/development/desa/en/news/sustainable/sustainabledevelopment-goals-report-2020.html.

Urban, B., \& George, J. (2018). An empirical study on measures relating to impact investing in South Africa. International Journal of Sustainable Economy, 10(1), 61-77.

Uyar, A., Karaman, A. S., \& Kilic, M. (2020). Is corporate social responsibility reporting a tool of signaling or greenwashing? Evidence from the worldwide logistics sector. Journal of Cleaner Production, 253, 119997.

Van Der Laan, S., \& Lansbury, N. (2004). Socially responsible investing and climate change: Contradictions and challenges. Australian Accounting Review, 14(34), 21-30.

Van Eck, N. J., \& Waltman, L. (2017). Citation-based clustering of publications using CitNetExplorer and VOSviewer. Scientometrics, 111(2), 1053-1070.

Vanderheiden, S. (2015). Justice and climate finance: Differentiating responsibility in the Green Climate Fund. The International Spectator, 50(1), 31-45.

Vazquez, K. C., \& Chin, G. T. (2019). The AIIB and sustainable infrastructure: A hybrid layered approach. Global Policy, 10(4), 593-603.

Viviani, J. L., \& Maurel, C. (2019). Performance of impact investing: A value creation approach. Research in International Business and Finance, 47, 31-39.

Viviers, S., \& Eccles, N. S. (2012). 35 years of socially responsible investing (SRI) research-general trends over time. South African Journal of Business Management, 43(4), 1-16.

Viviers, S., Ractliffe, T., \& Hand, D. (2011). From philanthropy to impact investing: Shifting mindsets in South Africa. Corporate Ownership and Control, 8(3-1), 25-43.

Von Wallis, M., \& Klein, C. (2015). Ethical requirement and financial interest: A literature review on socially responsible investing. Business Research, 8(1), 61-98.

Wang, C. (2013a). Conscious capitalism firms: Do they behave as their proponents say? California Management Review, 55(3), 60-86.

Wang, C. (2013b). On the scientific status of the conscious capitalism theory. California Management Review, 55(3), 97-106.

Wang, C. N., Larsen, M. L., \& Wang, Y. (2020). Addressing the missing linkage in sustainable finance: The 'SDG Finance Taxonomy.' Journal of Sustainable Finance \& Investment. https://doi.org/10.1080/ 20430795.2020.1796101 in press.

Watson, R. (2011). Ethical and socially responsible investment funds: Are they ethically and responsibly marketed? Journal of Financial Regulation and Compliance, 19(2), 100-110. 
Widyawati, L. (2020). A systematic literature review of socially responsible investment and environmental social governance metrics. Business Strategy and the Environment, 29(2), 619-637.

Wilson, R. (1997). Islamic finance and ethical investment. International Journal of Social Economics, 24(11), 1325-1342.

Yao, S., Pan, Y., Sensoy, A., Uddin, G. S., \& Cheng, F. (2021). Green credit policy and firm performance: What we learn from China. Energy Economics, 101, 105415.

Yenneti, K., \& Gamaralalage, P. J. D. (2012). Carbon finance and decentralized composting in Asia: Potential and future considerations. Environment and Urbanization ASIA, 3(2), 303-323.

Yeoh, P. (2008). Is carbon finance the answer to climate control? International Journal of Law and Management, 50(4), 189-206.

Yesuf, A. J., \& Aassouli, D. (2020). Exploring synergies and performance evaluation between Islamic funds and socially responsible investment (SRIs) in light of the Sustainable Development Goals (SDGs). Heliyon, 6(8), e04562.

Yu, C. H., Wu, X., Zhang, D., Chen, S., \& Zhao, J. (2021). Demand for green finance: Resolving financing constraints on green innovation in China. Energy Policy, 153, 112255.

Yu, E. P. Y., Van Luu, B., \& Chen, C. H. (2020). Greenwashing in environmental, social and governance disclosures. Research in International Business and Finance, 52, 101192.

Zhang, D. (2021). How environmental performance affects firms' access to credit: Evidence from EU countries. Journal of Cleaner Production, 315, 128294.

Zhang, D., Zhang, Z., \& Managi, S. (2019). A bibliometric analysis on green finance: Current status, development, and future directions. Finance Research Letters, 29, 425-430.

Zhang, M., Lian, Y., Zhao, H., \& Xia-Bauer, C. (2020). Unlocking green financing for building energy retrofit: A survey in the western China. Energy Strategy Reviews, 30, 100520.

Zupic, I., \& Čater, T. (2015). Bibliometric methods in management and organization. Organizational Research Methods, 18(3), 429-472.

Publisher's Note Springer Nature remains neutral with regard to jurisdictional claims in published maps and institutional affiliations.

\section{Authors and Affiliations}

\section{Satish Kumar',2 ${ }^{1, D i p a s h a ~ S h a r m a ~}{ }^{3}$ Sandeep Rao ${ }^{4}$ Weng Marc Lim²,5 Sachin Kumar Mangla 6}

Sachin Kumar Mangla

smangla@jgu.edu.in; sachin.kumar@plymouth.ac.uk; sachinmangl@gmail.com

Satish Kumar

skumar.dms@mnit.ac.in

Dipasha Sharma

dipasha_sharma@scmhrd.edu

Sandeep Rao

sandeep.keshavarao@dcu.ie

Weng Marc Lim

lim@wengmarc.com; marclim@swin.edu.au; wlim@swinburne.edu.my

1 Department of Management Studies, Malaviya National Institute of Technology Jaipur, Jaipur, Rajasthan 302017, India

2 School of Business, Swinburne University of Technology, Jalan Simpang Tiga, 93350 Kuching, Sarawak, Malaysia

3 Symbiosis Centre for Management and Human Resource Development, Symbiosis International (Deemed University), Pune, India 
4 DCU Business School, Dublin City University, Dublin 09, Ireland

5 Swinburne Business School, Swinburne University of Technology, John Street, Hawthorn, VIC 3122, Australia

6 Jindal Global Business School, O P Jindal Global University, Sonipat, Haryana, India 